REVIEW ARTICLE

\title{
Medicinal Chemistry of Multiple Sclerosis: Focus on Cladribine
}

\author{
Tamás Biernacki ${ }^{1}$, Dániel Sandi ${ }^{1}$, Krisztina Bencsik $^{1}$ and László Vécsei ${ }^{1,2, *}$ \\ ${ }^{I}$ Department of Neurology, Szent-Györgyi Albert Clinical Center, University of Szeged, Szeged, Hungary; ${ }^{2}$ MTA-SZTE \\ Neuroscience Research Group, Szeged, Hungary
}

A R T I C L E H I S T O R Y

Received: August 27, 2018 Revised: April 28, 2019 Accepted: May 19, 2019

DOI

$10.2174 / 1389557519666191015201755$

\begin{abstract}
Background: In the recent years, many novel disease-modifying drugs (DMD) have been introduced to the market in the treatment of multiple sclerosis.

Objectives: To provide the reader with an up to date, compact review on the pharmacokinetic properties, mechanism of action, and clinical attributes of one of the most recently approved drugs in the therapy of multiple sclerosis, cladribine.

Conclusion: Cladribine tablets proved to be a highly efficient treatment choice for relapsing-remitting multiple sclerosis (RRMS), especially for patients with high disease activity. It is the first DMD for MS with a complex mechanism of action, by inhibiting the adenosine-deaminase enzyme it increases the intracellular levels of deoxyadenosine triphosphate, which with relative selectivity depletes both Tand B-cells lines simultaneously. However long term follow-up safety and effectiveness data are still missing, and clear treatment protocols are lacking beyond the first two treatment years cladribine should prove to be a valuable addition to the therapeutic palette of RRMS, and potentially for clinically isolated syndrome (CIS) as well.
\end{abstract}

Keywords: Cladribine, mechanism of action, multiple sclerosis, efficacy, safety, dosing.

\section{INTRODUCTION}

Multiple Sclerosis (MS) is a chronic inflammatory and neurodegenerative disease of the central nervous system (CNS). There are approximately 2.3 million MS patients worldwide [1]. Among young adults, MS is the most common cause of non-traumatic disability, it is the most common "rare disease" [2]. Its prevalence shows north to south gradient across the globe, it being the most common in the Scandinavian countries (150-200/100 000), roughly half of that in Central Europe (83.7/100 000), and having an even lower prevalence approaching the equator and in southern Baltic states $(20-50 / 100,000)$ [3-5]. In addition to being the most common "rare-disease", it doesn't just put a heavy strain on one's everyday quality of life - as it was presumed for long -, but it also increases the patients' mortality by 2.57 to 4.10 fold (depending on disease form and severity) [6].

More than 20 years ago the clinical courses of multiple sclerosis have been defined as benign, relapsing-remitting, primary progressive, secondary progressive, and progressive-relapsing MS by consensus statement of the international clinical MS community [7]. These disease course types are

*Address correspondence to this author at the Department of Neurology, Faculty of General Medicine, Albert Szent-Györgyi Clinical Centre, University of Szeged, Semmelweis u. 6., H-6725, Szeged, Hungary; Tel: +36-62545-384; Fax: +36-62-545-597; E-mail: vecsei.laszlo@med.u-szeged.hu not supported by neuroimaging or other kinds of biomarkers but were solely based on the clinical picture of the patients. Since then, a substantial amount of knowledge has been gathered regarding the pathophysiology, the nature of and biomarkers in MS. This has invoked a general concern that the "old" classification might not reflect the clinical aspects, the prognosis and the treatment requirement of one's disease with enough accuracy. Hence the classification system has been revised based on the past decades' improved descriptive technologies, biomarkers, imaging technologies and clinical experience $[8,9]$. The new classification system re-defined some terms used to describe one's disease. Among the redefined terms are disease activity ("clinical activity: relapses, acute or sub-acute episodes of new or increasing neurological dysfunction followed by full or partial recovery, in the absence of fever or infection or evidence of a pseudorelapse", "imaging: occurrence of contrast-enhancing T1 hyperintense lesions or new or unequivocally enlarging $\mathrm{T} 2$ hyperintense lesions. The term 'unequivocally' has been added to highlight the importance of aligning successive scans as closely as possible when gauging enlarging lesions"), progression (clinical: steadily increasing objectively documented neurological dysfunction/disability without unequivocal recovery; fluctuations and phases of stability may occur, imaging: no standardized imaging measures of disease progression are currently established; however, measures, 
such as an increasing number and volume of T1 hypointense lesions, brain volume loss and changes in magnetization transfer imaging and diffusion tensor imaging are being explored), disease worsening ("is defined as a documented increase in neurological dysfunction/disability as a result of relapses or progressive disease or both") and confirmed progression or worsening ("is an increase in neurological dysfunction confirmed throughout a defined time interval (e.g. 3,6 or 12 months); this distinction is particularly relevant in the clinical trial setting $[8,9]$. Given that neurological dysfunction may improve (especially in relapsing-remitting MS) even if initially confirmed, it is recommended that the term 'sustained' be abandoned unless the disease has been measured over "a long period of time" [8,9]. Based on the new classifications system a person's disease can be classified as a clinically isolated syndrome (CIS) with or without activity, relapsing-remitting with or without activity, progressive active with or without progression, inactive with or without progression [10]. Radiologically isolated syndrome (RIS) was omitted and is not considered to be part of the MS spectrum disease anymore [10].

Table 1. Novel classification of MS subtypes. Activity determined by clinical relapses assessed at least annually and/or MRI activity (contrast-enhancing lesions; new and unequivocally enlarging $\mathrm{T} 2$ lesions).

\begin{tabular}{|c|c|}
\hline \multicolumn{2}{|c|}{ Novel MS Subtype Classification [6] } \\
\hline \hline \multirow{2}{*}{$\begin{array}{c}\text { Clinically isolated } \\
\text { syndrome (CIS) }\end{array}$} & Not active* \\
\cline { 2 - 2 } Relapsing-remitting (RR) & Active \\
\cline { 2 - 2 } & Not active \\
\hline \multirow{4}{*}{ Progressive disease } & Active \\
\cline { 2 - 2 } & Active - without progression** \\
\cline { 2 - 3 } & Active - with progression \\
\cline { 2 - 3 } & $\begin{array}{c}\text { Not active }- \text { without progression } \\
\text { (stable disease) }\end{array}$ \\
\cline { 2 - 3 } & Not active - with progression \\
\hline
\end{tabular}

** Progression measured by clinical evaluation, assessed at least annually. If assessments are not available, activity and progression are "indeterminate" [6].

\subsection{Pathomechanism}

Although a great number of studies have been dedicated to revealing the exact cellular and molecular pathomechanism of multiple sclerosis, the picture behind it is still unclear in many aspects. What is the first step in developing the disease? In spite of the fact that most findings agree that MS is primarily an immunological disease where secondary neurodegeneration is involved, there is some convincing evidence pointing towards the opposite direction i.e. the underlying process may be neurodegeneration itself with the secondary involvement of the immune system $[11,12]$. Yet, as the therapies used for slowing the progression and lowering the relapse rate are primarily immunotherapies - and those therapies are effective in halting the disease - we try to con- centrate on the immunological aspect of MS in this review [13].

\subsubsection{The Role of T-Cells}

MS is primarily considered to be initialized by the activation and migration of autoreactive Th- 1 and Th-17 cells into the CNS, mainly targeting MBP, MOG and HspB5 antigens [14-16]. The arrival of these autoreactive cells initiates a cascade which by recruiting and activating both the cellular and the humoral pathways of the immune response gradually leads to demyelination and to subsequent neurodegeneration. Evidence was supplied for this theory by many studies: beginning with the fact, that autoreactive T-cells were found in all 4 types of MS lesions throughout pathological examinations as described by Lucchinetti et al. [17]. Through in vivo animal studies, other evidence was found: EAE-prone mice were found to produce a large amount of IFN- $\gamma$, one of the primary inflammatory cytokines produced by Th-1 cells, which neutralizes IL-12, an anti-inflammatory cytokine, whereas Th- 2 responses and the inhibition of IL-4 cytokine release is prominent in animals resistant to EAE [18]. It was also shown, that the T-cells of MS patients produce far more IFN- $\gamma$ than the T-cells of healthy controls, suggesting an important role in CNS inflammation [19]. Furthermore, the dysregulation of T-regulatory and Th-17 cells has been found: these cell types have a similar development pathway and some studies showed that the development of Th-17 cells is up-regulated in MS as compared to other subtypes $[20,21]$. These cells were also shown to be the most damaging to the blood-brain barrier (BBB) [15]. Other studies concluded that the other regulatory subsets of T-cells - under specific circumstances - may become proinflammatory T-17 cells [22]. All these factors lead to myelin damage and axonopathy, first initializing, then sustaining the inflammation in the CNS.

The role of CD8+ T-cells is less understood, but seems nonetheless important. Classically, these cells were named "T-killer" cells due to their cytotoxic potential. Yet, more recent evidence points to the regulatory capabilities of $\mathrm{CD} 8+$ T-cells, as a factor in MS [23]. It seems that specific types of these cells are involved in the protection against inflammatory processes as they suppress the activation of $\mathrm{CD} 4+$ pathways, thus the down-regulation of these cells play part in the autoimmune process [23].

\subsubsection{The Role of B-Cells}

Several facts show the direct involvement of the humoral pathway, thus B-cells in the pathology of MS, the presence of oligoclonal gammopathy (OGP) being the most obvious [24]. Many studies concluded, however, that this activation is secondary and unspecified, and it plays an important role in the de facto degradation of myelin and damage of the axons [24-26]. However, other, newer evaluations found, that some peripheral nervous system-specific antibodies are capable of activating CNS-specific T-cells, thus playing an important part in the initialization of the inflammatory process while still in the periphery [24]. Also, another aspect of B-cells seems to be highly important in the immunopathomechanism: B-cells are effective and specific antigen- 
presenting agents through major histocompatibility complex II (MHC-II) and B-cell receptor (BCR) molecules, playing a pivotal role in activating and promoting the differentiation of T-cells toward the proinflammatory path [27-29]. In recent studies, the presence of both myelin-recognizing $\mathrm{B}-$ and $\mathrm{T}$ cells successfully induced EAE $[30,31]$. The other important factor is the role of the regulating B-cell population and the production of cytokines. Several studies indicate, that the chronic activation of B-regulatory cells producing mainly proinflammatory cytokines (e.g. IL-6), thus leading to the shift toward proinflammatory T-cell populations is a major correspondent in CNS inflammation [24]. For instance, the genetically modified, B-cell restricted IL-6 deficient mice population showed a far less severe course of EAE and Th17 cell numbers $[32,33]$. Also, the levels of secreted IL-6 and other proinflammatory cytokine levels are definitely higher in the B-cells derived from MS patients than from healthy controls [33]. On the other hand, studies showed that the activation of anti-inflammatory cytokine-producing Bcells relates to a less severe course [24, 34].

As described above, the pathomechanism of MS is a very complex process involving most cellular parts of the immune system, however, this process is still unclear in many aspects. Yet, it is important to see, that these diverse immunological dysfunctions all play important parts in the initiation and sustaining of the CNS inflammation, thus therapies targeting these processes can-, and have been proven beneficial.

\subsection{Therapy of MS}

Currently, MS is an incurable condition: current treatments focus on slowing the disease progression by reducing the inflammation in the CNS, lowering the relapse-rate and slowing the emergence of disability. There are several unmet needs, considering MS therapy, aside from a definitive cure. It is a heavy burden for both the patients and the medical service providers, that current disease-modifying therapies (DMT) - except for alemtuzumab - should be used and monitored continuously for decades. Because of constant immunosuppression, patients are more prone to opportunistic infections. The efficacy of the injectable DMTs (interferon- $\beta$ and glatiramer-acetate) is lower than the newer therapies, they often cause local side effects, thus patients often cannot tolerate the long-term use. On the other hand, the higher effectivity of monoclonal antibodies (natalizumab, alemtuzumab, ocrelizumab, daclizumab), which are not taken daily, can lead to serious side effects (progressive multifocal leukoencephalopathy (PML) with natalizumab, daclizumab, which was withdrawn from the market in early 2018 due to severe, potentially lethal side effects, listeriosis following treatment with alemtuzumab) [35-37]. The effectivity of per os drugs is similar to the injectable DMTs, but they require regular blood test control, some should be taken more than once a day and in case of missed doses or stopping the treatment, their effect fades away fast. Cladribine offers a solution to some of these problems: it is used in four, five-days cycle in the first 2 years, it is taken per os, it has a long-lasting effect and the side effect profile is comparable to current DMTs [38].

\section{CLADRIBINE}

2-chloro-2'-deoxyadenosine (2-CdA, Cladribine) was first synthetized in 1972, following the discovery of a new form of severe combined immunodeficiency (SCID). Dr. Ernest Beutler and Dr. Dennis A. Carson had been studying a new form of SCID, which was discovered to be caused by the deficiency of the adenosine-deaminase enzyme. Because of the defect in the enzyme, deoxy-adenosine-triphosphate levels increase inside the cells, causing the destruction of $\mathrm{T}$ and B lymphocytes and subsequently leading to immunodeficiency [39]. This revelation leads to the idea, that a drug with a similar mechanism of action might be suitable to treat lymphomas. Cladribine was found to be able to achieve prolonged remission in patients with hairy cell leukemia (HCL), a previously untreatable disease [40]. In 1993, intravenous cladribine was approved by both the Food and Drug Administration (FDA) in the U.S.A, and by the European Medicines Agency (EMA) in Europe for the treatment of HCL as an orphan drug. A subcutaneous form with the same indication was also developed later, and introduced to the market [41].

Following its approval in the treatment of HCL, several clinical trials have been conducted in order to explore the potential efficacy of cladribine in MS, based on its potent immunosuppressive effect on both $\mathrm{T}$-, and $\mathrm{B}$ cell lines. The first attempt for its approval in the treatment of MS was in 1997, however, the application was withdrawn from the FDA on the grounds of insufficient clinical data. After an oral version of the drug was developed a new application was submitted, which was first rejected by the EMA in 2010, and then by the FDA in 2011 due to concerns that an increased number of cancers have arisen amongst the patients treated with cladribine, and the ratio of benefit to harm was not clear to the regulators at the time with the amount of data available. At the time of the rejections, clinical trials were still ongoing, which were not terminated. Meta-analysis of data from these trials had shown that cladribine did not increase the risk of cancer at the doses used. Following this, a new application was submitted to the regulatory agencies, on June 22, 2017, the EMA approved the use of cladribine for the treatment of relapsing-remitting multiple sclerosis.

\subsection{Mechanism of Action}

The mechanisms of action of the current DMTs lie in either immunomodulation, immunosuppression, or the inhibition of leukocyte migration. Cladribine has a combined effect: it has an immunomodulatory effect by pushing the cytokine rate towards the direction of anti-inflammatory cytokines; and an immunosuppressive effect by depleting both the $\mathrm{T}$ - and the B-lymphocyte populations.

\subsubsection{The Immunosuppressive Effect}

Cladribine is a purine analog that differs from deoxyadenosine (DA) in only a chlorine atom on the 2 nd C-atom of the purine frame [39]. As the deoxy-nucleosides enter the cells, they are phosphorylated by the deoxycytidine kinase $(\mathrm{dCK})$, an intracellular enzyme. From deoxyadenosine, it creates deoxy-adenosine-monophosphate (dAMP) in the first step, then diphosphate (dADP), and triphosphate (dATP) 


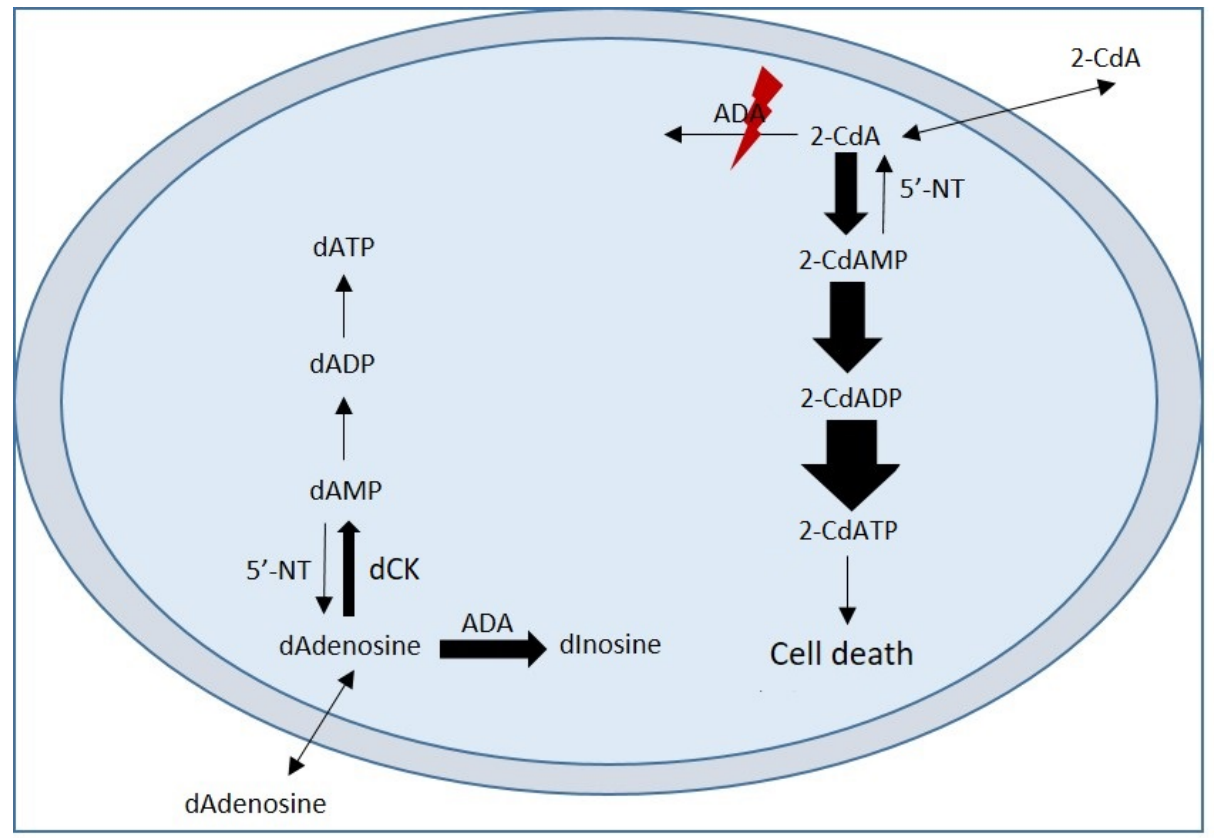

Fig. (1). The accumulation of chloro-deoxynucleotides caused by cladribine. ADA - adenosine deaminase, 2-CdA - 2-chloro-2'deoxyadenosine (cladribine), dCK - deoxycitidine kinase, 5'NT - 5' nucleotidase, dAMP - deoxyadenosine monophosphate, dADP - deoxyadenosine diphosphate, dATP - deoxyadenosine triphosphate, 2-CdAMP - 2-chloro-2'-deoxyadenosine-monophosphate, 2-CdADP - 2chloro-2'-deoxyadenosine-diphosphate, 2-CdATP - 2-chloro-2'-deoxyadenosine-triphosphate. (A higher resolution/colour version of this figure is available in the electronic copy of the article).

[39]. Cladribine becomes 2-chloro-2'-deoxy-ß-D-adenosine monophosphate (2-CdAMP), then diphosphate, finally also triphosphate (2-CdATP) [42]. The same process occurs in the mitochondria, except there, the phosphorylation is done by the deoxy-guanosine kinase enzyme [42]. The intracellular degradation of adenosine-nucleosides to deoxy-inosines is done by the adenosine deaminase (ADA). The intracellular adenosine nucleoside-nucleotide rate is determined by the dCK-ADA rate (kinase-phosphatase rate), compared to other cells, this rate is higher in lymphocytes [42]. Cladribine is a substrate to $\mathrm{dCK}$, but resistant to ADA, as the halogenation of the adenine ring with chlorine leads to such changes in the molecules' electron-distribution, that makes the amine-group resistant to hydrolyzing by ADA [43]. Thus, due to the high kinase-phosphatase rate in lymphocytes, cladribine accumulates fast in the cells, generating a high amount of 2-CdATP. The accumulated 2-CdATP is toxic to both the resting and the dividing lymphocytes. This cytotoxicity of cladribine is due to its influence on multiple intracellular pathways.

\subsubsection{Inhibition of DNA-synthesis}

Cladribine inhibits the DNA-synthesis in multiple ways. Among other enzymes, the ribonucleoside-reductase (RR) supplies the needed amount of deoxy-ribonucleosidetriphosphates for DNA-synthesis, by creating deoxyribonucleoside-diphosphates from ribonucleoside diphosphates, which are phosphorylated further to triphosphates, which can enter the DNA-synthesis [44]. Cladribine is a highly effective inhibitor of RR, it can reversibly inhibit the enzyme even at $0.06 \mu \mathrm{M}$ intracellular concentration [45].
Also - as it is a purine-analog - it is a substrate of DNApolymerase, thus incorporates into the synthetizing DNAchain causing a chain-termination reaction. As cladribine inhibits the RR, it lowers the rate of available deoxyribonucleoside triphosphates, therefore increasing the chance of its own incorporation into the DNA-synthesis by DNApolymerase, further increasing its toxicity $[46,47]$.

\subsubsection{The Inhibition of DNA-repair}

The key step in many DNA-repair mechanisms is to cut out and replaced the damaged DNA section. As the repair of the DNA is a constant process in resting cells as well, there is always a need for freshly synthetized DNA-chains for the replacement of damaged sections. Cladribine can incorporate into these freshly synthetized sections, thus causing chain termination and making it impossible to repair the errors in the DNA-chain, leading to fast degradation [46-49]. Studies show, that the incorporated cladribine inhibits the $\beta$-DNApolymerase, an essential enzyme in the DNA-repair process, and found a positive correlation between the amount of these incorporated purine-analogs and the number of destructed cells [46-49].

\subsubsection{Apoptosis}

The third potential mechanism of cladribine for immunosuppression is the induction of apoptosis in lymphocytes. Cladribine incorporation leads to chain termination, which is perceived by the cell as if the DNA-double helix was broken. The poly-ADP-ribose-polymerase (PARP) and other enzymes perceive the errors and activate the downstream signal pathways, which lead to either the repair of the DNA or to 


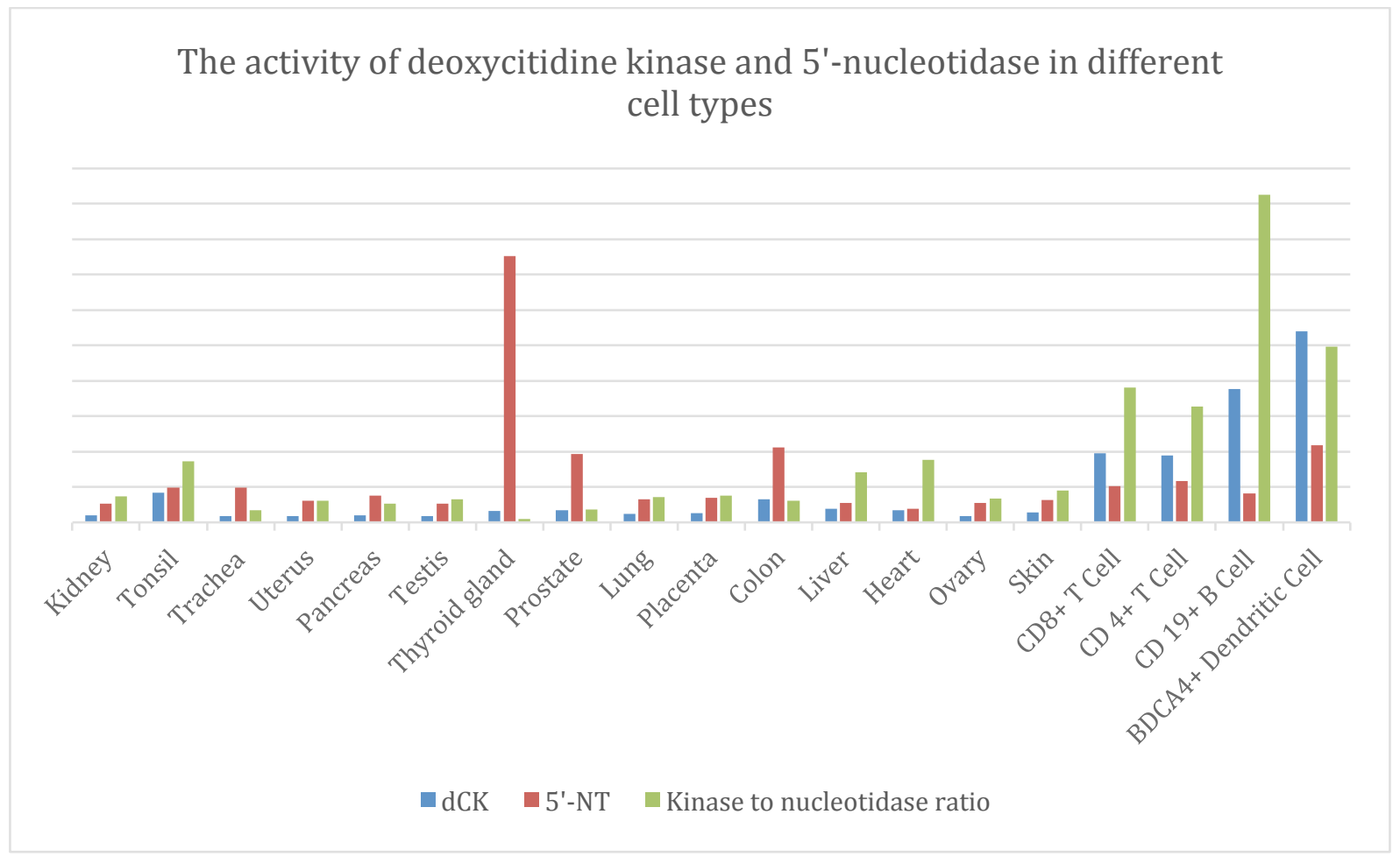

Fig. (2). The activity of deoxycytidine kinase and 5'-nucleotidase in different cell types. dCK - Deoxycytidine kinase, 5'-NT - 5' nucleotidases. Y axis values are displayed in TPM (transcripts per million) units. (A higher resolution/colour version of this figure is available in the electronic copy of the article).

cell death $[50,51]$. As the cascade, induced by the DNA errors, begins, the p53 molecule activates, which in turn, activates other transducer molecules, including p21 [52]. The increasing p21 stops the cell cycle by the inhibition of cyclin-dependent kinase 2 (CDK-2), for either repair or if not possible, for cell death; as cladribine inhibits the DNArepair, it induces the apoptosis pathway at this point [52-57].

In sensitive cell culture lines, the morphological and biochemical signs can be seen following incubation with cladribine. In order to be able to activate and execute the programmed cell death cells need to contain a ubiquitous, multi-purpose cysteine protease protein family, called caspases. These proteins can cleave and thus activate or degrade numerous structural, nuclear, signaling and effector proteins, some of which play a pivotal role in the apoptotic cascade. The caspases can be activated by two separate pathways, the first is of mitochondrial origin ("intrinsic pathway"), while the second one is triggered by the activation of cell surface receptors, called the "extrinsic pathway" [58].

Cladribine produces its effect primarily by the activation of the intrinsic pathway. Triggering the intrinsic pathway causing an increase in the permeability of the mitochondrial membrane. This can be achieved either by the incorporation of pore-forming molecules into the membrane or by the activation of an already present pore-forming complex, the mitochondrial permeability transition pore (mtPTP) [43]. The opening of the external membrane of the mitochondria creates the opportunity for various apoptosis-inducing molecules (including Cytochrome $\mathrm{C}$ and apoptosis-inducing fac- tor - AIF) residing in the intermembranous space, to exit the mitochondria and enter the cytosol. The Cytochrome $\mathrm{C}$ now inside the cytosol can activate the first member of the intrinsic caspase cascade, namely the Caspase-9, whereas AIF enters the nucleus and causes the fragmentation of the DNA chain by a mechanism independent of the caspase cascade [59-65].

The extrinsic pathway is triggered by the activation of various ligands and receptors, such as Fas (CD95/Apo-1), TNF receptor 1 (TNF-R1) and death receptors (DR-3, -4, -5). The activation can be induced by the binding of either cell surface bound or soluble ligands, like Fas-L (CD 95), TNF-a and TNF-related apoptosis-inducing ligand (TRAIL) [66]. The binding of these ligands is followed by the recruitment of support molecules, which results in the activation of caspase- 8 , the first molecule in the extrinsic caspase cascade [43]. Caspase- 8 is capable of cleaving Bid, a pro-apoptotic molecule of the protein family Bcl-2. The now active Bid causes the release of Cytochrome $\mathrm{C}$ into the cytosol; thus the extrinsic pathway is capable of activating the intrinsic pathway as well. Another downstream effect of Bid includes interaction with Caspase-2, which leads to the activation of further molecules, and eventually, the two pathways converge and activate Caspase-3, and the apoptosis follows afterward [64].

\subsubsection{Immunomodulant Effect}

In addition to its leukocyte depleting effect, it was shown in vitro that cladribine possesses immunomodulant attribute 
Table 2. The recommended dosing regimen for patients receiving cladribine by the number of tablets taken during treatment [70].

\begin{tabular}{|c|c|c|c|c|c|}
\hline Total Number of Tablets per Week & Day 1 & Day 2 & Day 3 & Day 4 & 1 \\
\hline \hline 4 & 1 & 1 & 1 & 1 & 1 \\
\hline 5 & 1 & 1 & 1 & 1 & 1 \\
\hline 6 & 2 & 2 & 1 & 1 \\
\hline 7 & 2 & 2 & 2 & 1 \\
\hline 8 & 2 & 2 & 2 & 2 \\
\hline 9 & 2 & 2 & 2 & 1 \\
\hline
\end{tabular}

Table 3. The recommended dosing regimen for patients with different weight range receiving cladribine.

\begin{tabular}{|c|c|c|}
\hline Weight Range & The Dose in mg (Number of 10 mg Tablets) per Treatment Week \\
\hline \hline $\mathrm{kg}$ & Treatment week 1 & Treatment week 2 \\
\hline 40 to $<50$ & $40 \mathrm{mg}(4$ tablets $)$ & $50 \mathrm{mg}(4 \mathrm{tablets})$ \\
\hline 50 to $<60$ & $50 \mathrm{mg}(5$ tablets $)$ & $60 \mathrm{mg}(5 \mathrm{tablets})$ \\
\hline 60 to $<70$ & $60 \mathrm{mg}(6$ tablets $)$ & $70 \mathrm{mg}(7 \mathrm{tablets})$ \\
\hline 70 to $<80$ & $70 \mathrm{mg}(7$ tablets $)$ & $70 \mathrm{mg}(7 \mathrm{tablets})$ \\
\hline 80 to $<90$ & $80 \mathrm{mg}(8$ tablets $)$ & $80 \mathrm{mg}(8 \mathrm{tablets})$ \\
\hline 90 to $<100$ & $90 \mathrm{mg}(9$ tablets $)$ & $90 \mathrm{mg}(9 \mathrm{tablets})$ \\
\hline 100 to $<110$ & $100 \mathrm{mg}(10$ tablets $)$ & $100 \mathrm{mg}(10 \mathrm{tablets})$ \\
\hline 110 and above & $100 \mathrm{mg}(10$ tablets $)$ & \\
\hline
\end{tabular}

as well, it induces a shift in the balance of inflammatory cytokines towards the anti-inflammatory side. The pack of leukocytes which survived the initial depleting effect of cladribine showed a sustained (for up to 58 days), altered cytokine production imprint, namely had an increased output of anti-inflammatory cytokines, such as IL-4, -5, -10. The production of other cytokines (IL-6, -8, -17A, -23, TNFalpha and NGF-beta) remained unchanged [67].

\subsubsection{Pharmacokinetics}

Cladribine given orally has a bioavailability of $37-51 \%$, ingested with meals it is approximately $40.5 \%$, taken between meals $45.6 \%$, ingestion with food causes a net decrease in absorption as well as a delay in the absorption of cladribine [68]. The clearance of cladribine correlates well with the patient's creatinine clearance, the half-life of the molecule is between 5.7 and 19.4 hours depending on the renal function of the patient [68]. Mild, moderate and severe renal impairment decreases the clearance of cladribine by $19 \%, 30 \%$, and $40 \%$, respectively [69]. Protein binding of the molecule is approximately $20 \%$, the volume of distribution varies between $54-367 \mathrm{1} / \mathrm{m}^{2}$. The measured concentra- tion of cladribine in the CSF is roughly $1 / 4^{\text {th }}$ of that in the plasma [68].

\subsubsection{Dosage}

The currently approved and recommended cumulative dose of cladribine is $3.5 \mathrm{mg} / \mathrm{kg}$ body weight administered over 2 years, in 2 treatment courses ( 1 course each year). Each treatment course includes a dose of $1.75 \mathrm{mg} / \mathrm{kg}$ cladribine. Each treatment course consists of 2 treatment weeks, one at the beginning of the first month of treatment and one at the beginning of the second month of the respective treatment year. Each treatment week consists of 4 or 5 days, a patient receives $10 \mathrm{mg}$ or $20 \mathrm{mg}$ (one or two tablets) as a single daily dose, depending on body weight. The tablets should be taken approximately at intervals of 24 hours, if a daily dose consists of 2 tablets, then both should be taken at the same time. Following the completion of the 4 treatment courses, no further cladribine treatment is required in years 3 and 4 . Re-initiation of therapy after year 4 has not been approved yet [70].

Contraindications to initiating cladribine therapy are known hypersensitivity to the active substance or to any of 
Table 4. The therapeutic burden of different DMDs.

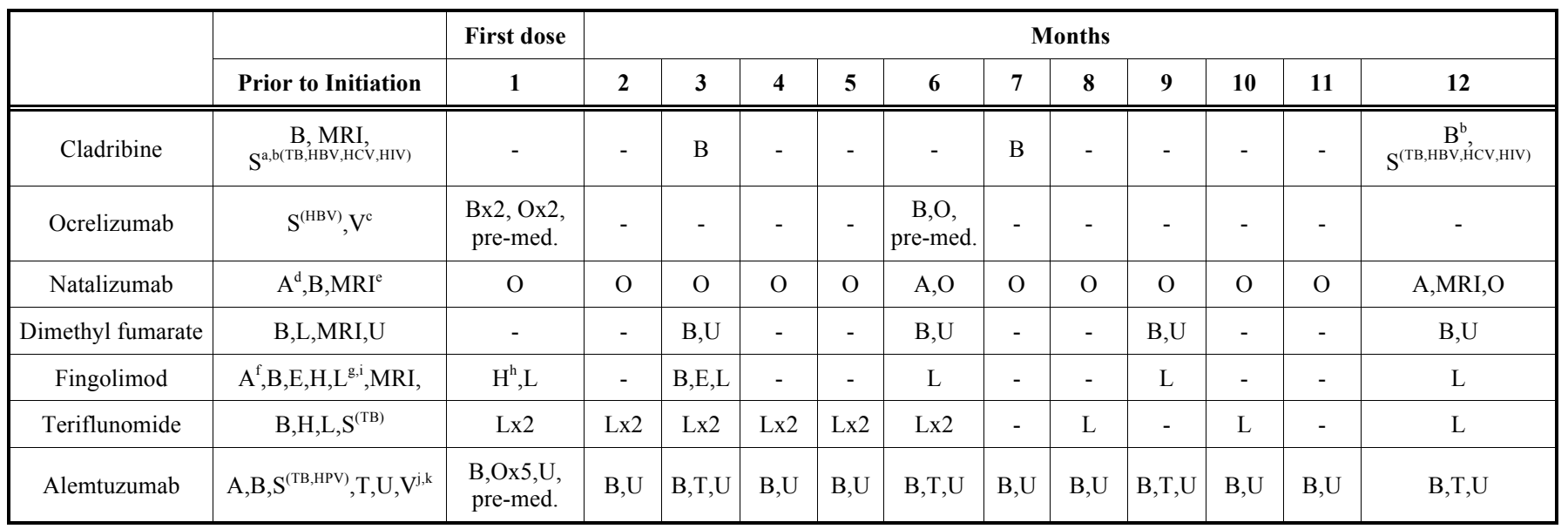

A - antibody testing, B - blood count, E - ophthalmology consultation, H - cardiovascular monitoring, L - liver function test, MRI - brain MRI scan, $\mathrm{O}$ - observation, $\mathrm{S}$ - screening, $\mathrm{T}$ - thyroid function test, $\mathrm{U}$ - urinalysis, $\mathrm{V}$ - vaccination. ${ }^{\mathrm{a}}$ - Blood lymphocyte counts must be normal before initiating cladribine tablets in Year 1 and at least $800 / \mathrm{mm}^{3}$ before initiating cladribine tablets in Year $2{ }^{\mathrm{b}}$ - Screening must be performed prior to initiation of therapy in Year 1 and Year 2. Vaccination of antibody-negative patients is recommended prior to initiation of cladribine therapy [72] ${ }^{\mathrm{c}}$ - Ocrelizumab is contraindicated in patients with active HBV confirmed by positive results for hepatitis virus B surface antigen [HBsAg] and anti-HBV tests. For patients who are negative for HBsAg and positive for $\mathrm{HB}$ core antibody [HBcAb+] or are carriers of $\mathrm{HBV}$ [HBsAg+], consultation with liver disease expert is recommended before starting and in treatment months 2 and 6 after the start of treatment in each treatment year, and as clinically indicated thereafter [73]. ${ }^{\mathrm{d}}-\mathrm{Test}$ for serum anti-JCV (JC virus) antibodies need to be done prior to treatment and then every 6 months. ${ }^{\mathrm{e}}$ - Before initiation of treatment, a recent (usually within 3 months) MRI should be available as a reference, and be repeated at least on a yearly basis. More frequent MRIs (e.g. on a 3-6 monthly basis) using an abbreviated protocol should be considered for patients at higher risk of PML [74]. ${ }^{\mathrm{f}}$ - It is recommended that patients without a healthcare professional confirmed the history of chickenpox or documentation of a full course of vaccination with varicella zoster virus (VZV) vaccine undergo antibody testing for VZV before initiating fingolimod therapy. A full course of vaccination for antibody-negative patients with varicella vaccine is recommended prior to commencing treatment. ${ }^{g}$ - Recent (i.e. within last 6 months) transaminase and bilirubin levels should be available before initiation of treatment with fingolimod. In the absence of clinical symptoms, liver transaminases should be monitored at months $1,3,6,9$ and 12 on therapy and periodically thereafter. If liver transaminases rise above 5 times the ULN, more frequent monitoring should be instituted, including serum bilirubin and alkaline phosphatase (ALP) measurement. With repeated confirmation of liver transaminases above 5 times the ULN, treatment with fingolimod should be interrupted and only re-commenced once liver transaminase values have normalized. ${ }^{\mathrm{h}}-\mathrm{Monitor}$ ECG and BP hourly for 6 hours after the first dose and regularly throughout treatment. ECG should also be taken prior to commencing treatment. ${ }^{\mathrm{I}}-\mathrm{An}$ ophthalmological evaluation is recommended for at-risk patients prior to initiation and for all patients at 3-4 months after treatment initiation. If patients report visual disturbances at any time while on therapy, evaluation of the fundus, including the macula, should be carried out. Patients with a history of uveitis and patients with diabetes mellitus are at increased risk of macular edema and it is recommended that these patients undergo an evaluation prior to initiating therapy and have follow-up evaluations while receiving therapy [75]. ${ }^{j}-$ Varicella zoster virus vaccination of antibody-negative patients should be considered prior to treatment initiation with alemtuzumab. Patients should have complete local immunization requirements at least 6 weeks prior to treatment with alemtuzumab. Patients without a history of chickenpox or without vaccination against VZV should be tested for antibodies to VZV; ${ }^{\mathrm{k}}-\mathrm{Human}$ papilloma virus screening should be completed annually for female patients treated with alemtuzumab [76]. Numbers indicate the number of days the monitoring tests occur within the specified month i.e. Ox 5 with alemtuzumab means observation is necessary 5 times that month $[77,78]$.

Table 5. Dosing frequency and burden of different DMDs.

\begin{tabular}{|c|c|c|c|c|c|c|c|c|c|c|c|c|c|}
\hline & \begin{tabular}{|c|} 
First Dose \\
1
\end{tabular} & \multicolumn{11}{|c|}{ Months } & $\begin{array}{c}\text { Total } \\
1 \text { Year }\end{array}$ \\
\hline Cladribine & 4-5 days & 4-5 days & - & - & - & - & - & - & - & - & - & - & $\begin{array}{c}\text { Max. } \\
20 \text { doses }\end{array}$ \\
\hline Ocrelizumab & $\begin{array}{l}2 \text { doses }+ \\
\text { pre-med. }\end{array}$ & - & - & - & - & - & $\begin{array}{l}1 \text { dose }+ \\
\text { pre-med. }\end{array}$ & - & - & - & - & - & 3 doses \\
\hline $\begin{array}{l}\text { Dimethyl } \\
\text { fumarate }\end{array}$ & 60 doses & 60 doses & 60 doses & 60 doses & 60 doses & 60 doses & 60 doses & 60 doses & 60 doses & 60 doses & 60 doses & 60 doses & 730 doses \\
\hline Fingolimod & 30 doses & 30 doses & 30 doses & 30 doses & 30 doses & 30 doses & 30 doses & 30 doses & 30 doses & 30 doses & 30 doses & 30 doses & 365 doses \\
\hline Teriflunomide & 30 doses & 30 doses & 30 doses & 30 doses & 30 doses & 30 doses & 30 doses & 30 doses & 30 doses & 30 doses & 30 doses & 30 doses & 365 doses \\
\hline Alemtuzumab & $\begin{array}{l}5 \text { doses }+ \\
\text { pre-med. }\end{array}$ & - & - & - & - & - & - & - & - & - & - & - & 5 doses \\
\hline
\end{tabular}

the excipients, infection with human immunodeficiency virus (HIV), active chronic infection (tuberculosis or hepatitis), immunocompromised patients of any kind, including patients currently receiving immunosuppressive or myelosuppressive therapy, active malignancy, moderate or severe renal impairment (creatinine clearance $<60 \mathrm{ml} / \mathrm{min}$ ), preg- 
nancy and breastfeeding. No studies have been conducted in patients with renal or hepatic impairment, no dosage adjustment is necessary among patients with mild renal impairment (creatinine clearance between 60 and $89 \mathrm{ml} / \mathrm{min}$ ) [70].

\subsubsection{Therapeutic Burden}

Choosing the right treatment for a patient is always a challenging task, since not only professional aspects (disease activity, concomitant morbidities, previous treatment failures, etc.) need to be taken into account, but also the patient's personal needs, the burden a given treatment places on the caregiver, the patient, and the healthcare system needs to be taken into evaluation as well, when deciding on a given DMD.

Beyond therapeutic efficacy and route of administration, there is a significant difference in the monitoring requirements and time management burden between current therapies for MS. In the first four years of therapy cladribine proved to lay the smallest amount of time management burden on both patients and caregivers when compared to fingolimod and alemtuzumab. Including patient workup, the drug delivery, monitoring, follow up visits, adverse event management and travel time treatment with cladribine consumed 25 hours, treatment with fingolimod took 103 hours and treatment with alemtuzumab required 193 hours of time in the first 4 years of treatment [71]. Monitoring requirements differ vastly between DMDs as well. Comparing cladribine to other DMDs (excluding the injectable interferons), cladribine has by far the smallest monitoring- and, administration burden, and requires the least amount of monitoring during therapy. Another advantage is that the drug itself needs to be taken in cycles, and only for 8-10 days, therefore the chance of missing a dosing regimen (in contrast with therapies that have to be taken more than once a day, every day), is minimal.

\subsubsection{Clinical Efficacy and Phase III Studies}

The CLARITY study was a pivotal, 96 weeks long, phase III, double-blind, multicenter, placebo-controlled trial. It enrolled a total of 1326 patients, they were approximately distributed in a 1:1:1 (433:456:437 patients for the $3.5 \mathrm{mg}$, $5.25 \mathrm{mg}$ and placebo groups respectively) ratio to receive either placebo or a cumulative dosage of oral cladribine of $3.5 \mathrm{mg} / \mathrm{kg}$ or $5.25 \mathrm{mg} / \mathrm{kg}$ body weight [38]. The study's primary endpoint was the patients' annualized relapse rate (ARR) at 96 weeks. Secondary clinical endpoints included the proportion of relapse-free patients, the time to acquire a sustained disability, the time to first relapse. Secondary MRI endpoints were the number of Gd-enhancing T1-weighted lesions, active T2-weighted lesions, and combined unique lesions at 96 weeks $[38,79]$. Of the 1326 enrolled patients $1184(89.3 \%)$ have completed the whole study $(91.9 \%$ in the cladribine $3.5 \mathrm{mg}$ group, $89.0 \%$ in the cladribine $5.25 \mathrm{mg}$ group and $87.0 \%$ in the placebo group) and 1165 (87.9\%) patients have completed treatment $(91.2 \%$ in the cladribine $3.5 \mathrm{mg}$ group, $86.2 \%$ in the cladribine $5.25 \mathrm{mg}$ group and $86.3 \%$ in the placebo group) [38]. The mean time of participation was 89.4 weeks $(91.0,89.4,87.8$ weeks respectively). Approximately $2 / 3^{\text {rd }}$ of patients had not received any disease-modifying drugs beforehand [38].
The most commonly used drugs were intramuscular interferon beta-1a (Avonex, 11.2\% of patients), subcutaneous interferon beta- $1 \mathrm{~b}$ (Betaferon, $10.6 \%$ of patients), subcutaneous interferon beta-1a (Rebif, 9.4\% of patients), and subcutaneous glatiramer acetate (Copaxone, $6.5 \%$ of patients), data are shown as mean (standard deviation (SD)), unless stated otherwise.

The primary endpoint was met in both groups receiving treatment, the ARR was found to be 0.14 in the cladribine $3.25 \mathrm{mg}$ group and 0.15 in the $5.25 \mathrm{mg}$ group compared to 0.33 in the placebo group meaning a relative reduction of $57.6 \%$ and $54.5 \%$ respectively $(\mathrm{p}<0.001)$. The cumulative number of relapses at 96 weeks was significantly lower in both cladribine groups versus placebo $(109,114$ and 252 relapses respectively). The number of relapse-free patients was $345(79.7 \%), 360(78.9 \%)$ for the 3.5 and $5.25 \mathrm{mg}$ groups compared to $266(60.9 \%)$ patients in the placebo group $(\mathrm{p}<0.001)$. The time to first relapse was significantly longer in both groups receiving treatment (hazard ratio [HR] in the $3.5 \mathrm{mg}$ group was 0.44 with a $95 \%$ CI of 0.34 to 0.58 , with the $15^{\text {th }}$ percentile of time to the first relapse being 13.4 months, while the HR in the cladribine $5.25 \mathrm{mg}$ group was 0.45 with a $95 \%$ CI of 0.36 to $0.60,15^{\text {th }}$ percentile to event being 13.3 months, $p<0.001$ for both groups) versus placebo ( $15^{\text {th }}$ percentile being 4.6 months). [38]

Treatment with cladribine demonstrated a significant relative risk reduction in the accumulation of 3-month sustained progression of disability as well as compared with placebo. A reduction of $33 \%$ was seen in the $3.5 \mathrm{mg}$ group (HR $0.67,95 \%$ CI 0.48 to $0.93, \mathrm{p}=0.02$ ), as well as a $31 \%$ reduction in the $5.25 \mathrm{mg}$ group (HR $0.69,95 \%$ CI 0.49 to $0.96, \mathrm{p}=0.03$ ). The time to 3 -month sustained change in the EDSS score was significantly longer in both arms receiving treatment (13.6 months in both groups) versus 10.8 months with placebo $[38,80]$.

As for MRI outcomes, when assessing the whole cohort compared with placebo, cladribine treatment proved to alleviate lesion burden in both groups. Patients in the treated groups had fewer Gd-enhancing T1 lesions (mean number $0.12(85.7 \%$ reduction $)$ and 0.11 (87.9\% reduction) for the $3.5 \mathrm{mg}$ and $5.25 \mathrm{mg}$ cohorts, respectively $v s .0 .91$ for placebo), active T2 lesions (0.38 [73.4\% reduction] and 0.33 [76.9\% reduction] vs. 1.48 respectively) as well as combined unique lesions (0.43 [74.4\% reduction], 0.38 [77.9\% reduction] $v s .1 .72$ respectively), $\mathrm{p}<0.001$ for all comparisons versus placebo. When the patients were stratified by baseline relapse rate the reductions in combined unique lesions in the 3.5 and $5.25 \mathrm{mg}$ cladribine groups were $74.8 \%$ and $75.5 \%$ ( $\leq$ 1 relapse), $83.1 \%$ and $86.7 \%$ ( 2 relapses), and $76.7 \%$ and $90.0 \%$ ( $\geq 3$ relapses), respectively ( $p<0.001$ for all comparisons). When divided by the presence of $\mathrm{T} 1 \mathrm{Gd}$-enhancing lesions at baseline a reduction of $73.5 \%$ and $75.2 \%$ was seen for patients without Gd-enhancing lesions and $80.8 \%$ and $84.9 \%$ was seen for patients with at least 1 Gd-enhancing lesion at baseline, respectively ( $<<0.001$ for all comparisons. The improvements in MRI outcomes seen were also confirmed in all clinically relevant patient subgroups stratified by disease severity at baseline [38]. 
Table 6. Baseline demographics and disease characteristics of treatment groups in the CLARITY study.

\begin{tabular}{|c|c|c|c|c|}
\hline \multicolumn{5}{|c|}{ Clarity } \\
\hline- & - & $(n=437)$ & $3.5 \mathrm{mg} / \mathrm{kg}(\mathrm{n}=433)$ & $5.25 \mathrm{mg} / \mathrm{kg}(\mathrm{n}=456)$ \\
\hline \multirow{2}{*}{ Age } & mean & $38.7 \pm 9.9$ & $37.9 \pm 10.3$ & $39.1 \pm 9.9$ \\
\hline & range & $18-64$ & $18-65$ & $18-65$ \\
\hline Mean weight - kg & & $70.3 \pm 15.4$ & $68.1 \pm 14.6$ & $69.3 \pm 14.8$ \\
\hline \multirow[t]{3}{*}{ Race - no. (\%) } & White & $429(98.2 \%)$ & $425(98.2 \%)$ & $446(97.8 \%)$ \\
\hline & Black & $1(0.2 \%)$ & $2(0.5 \%)$ & $4(0.9 \%)$ \\
\hline & Other & $7(1.6 \%)$ & $6(1.4 \%)$ & $6(1.3 \%)$ \\
\hline \multirow{7}{*}{ EDSS Score } & 0 - no. $(\%)$ & $13(3.0 \%)$ & $12(2.8 \%)$ & $11(2.4 \%)$ \\
\hline & $1-$ no. $(\%)$ & $70(16.0 \%)$ & $75(17.3 \%)$ & $80(17.5 \%)$ \\
\hline & 2 - no. $(\%)$ & $127(29.1 \%)$ & $133(30.7 \%)$ & $119(26.1 \%)$ \\
\hline & 3 - no. $(\%)$ & $96(22.0 \%)$ & $108(24.9 \%)$ & $108(23.7 \%)$ \\
\hline & 4 - no. $(\%)$ & $83(19.0 \%)$ & $71(16.4 \%)$ & $84(18.4 \%)$ \\
\hline & $\geq 5$ - no. (\%) & $48(11.0 \%)$ & $34(7.9 \%)$ & $54(11.8 \%)$ \\
\hline & Mean score & $2.9(1.3)$ & $2.8(1.2)$ & $3.0(1.4)$ \\
\hline
\end{tabular}

The annualized percentage brain volume change $(\mathrm{PBVC} / \mathrm{y})$ was evaluated $[81,82]$. Treatment with cladribine had a significant reduction on the PBVC/y for both arms $([-0.56 \% \pm 0.68 ; \mathrm{p}=0.010]$ for the $3.5 \mathrm{mg} / \mathrm{kg}$ group and $[-0.57 \% \pm 0.72 ; \mathrm{p}=0.019]$ for the $5.25 \mathrm{mg} / \mathrm{kg}$ group) compared with placebo $(-0.70 \% \pm 0.79)$. When the patients were stratified by the presence of Gd enhancing lesions at baseline no significant difference could be demonstrated in the PBVC/y between the three arms $(-0.92 \% \pm 1.02 \%, \mathrm{n}=110$ $-1.00 \% \pm 1.08 \%, \mathrm{n}=115 ;-0.97 \% \pm 0.97 \%, \mathrm{n}=106<3.5$ $\mathrm{mg} / \mathrm{kg}, 5.25 \mathrm{mg} / \mathrm{kg}$ cladribine and placebo, respectively) [82]. Subdividing the patients by PBVC/y the patients with the lowest brain volume loss (BVL) (PBVC/y>-0.4\%) showed the highest chance of being free from disability progression, meanwhile patients with the highest BVL $(\mathrm{PBVC} / \mathrm{y}<-1.08 \%)$ had the lowest probability of being disability free at the end of the second year (HR $0.67,95 \%$ CI 0.571 to $0.787 ; \mathrm{p}<0.001$ ) [82].

Various posthoc analyses were conducted after the completion of the CLARITY study. One assessed the NEDA (no evidence of disease activity) status of the participants [83]. Over 24, 48 and 96 weeks $67.3 \%, 69.7 \%$ versus $38.9 \%$;
$54.2 \%$ and $56.1 \%$ versus $23.9 \%$ and $44.2 \%$ and $46.0 \%$ versus $15.8 \%$ of the patients were found to be free of disease activity $(3.5 \mathrm{mg} / \mathrm{kg}, 5.25 \mathrm{mg} / \mathrm{kg}$ and placebo, respectively, $\mathrm{p}<0.001$ for all comparisons). In regard to previous treatment status (already treated with other DMDs $v s$. treatment naïve patients), disease duration significant difference was seen between the proportion of patients fulfilling the NEDA criteria. $37.2 \%$ and $42.9 \%$ vs. $16.2 \%$ of patients who already have received another $\mathrm{DMD}(\mathrm{s})$ were confirmed to have no evidence of activity $(3.5 \mathrm{mg} / \mathrm{kg}, 5.25 \mathrm{mg} / \mathrm{kg}$, placebo, respectively), this ratio in the case of treatment naïve patient was to be found $45.0 \%, 45.0 \%$ vs. $15.9 \%$ ). When stratifying base on baseline disease duration $38.1 \%, 46.5 \%$ vs. $8.2 \%$ of patients fulfilled the NEDA criteria with less than 3 years of disease history, with 3 to 10 years the ratio was $47.0 \%$, $40.3 \%$ vs. $15.5 \%$, meanwhile with a longer history than 10 years it was $41.8 \%, 47.8 \%$ vs. $22.1 \%(3.5 \mathrm{mg} / \mathrm{kg}, 5.25$ $\mathrm{mg} / \mathrm{kg}$, placebo, respectively, $\mathrm{p}<0.001$ for all comparisons). The ORs for remaining disease activity free while on treatment versus no treatment 3.99 [95\% CI 2.89 to 5.49] and 4.24 (95\% CI 3.09 to 5.82 ) for $3.5 \mathrm{mg} / \mathrm{kg}$ and $5.25 \mathrm{mg} / \mathrm{kg}$ doses respectively, $\mathrm{p}<0.001$ for each comparison [84]. 
Another posthoc analysis of the $3.5 \mathrm{mg} / \mathrm{kg}$ treatment arm sought to assess the treatment effect of the approved dosage of cladribine based on different baseline patient characteristics compared with the overall study population [85]. In this posthoc analysis patients with high disease activity (HDA), (the European Medicines Agency [EMA] has previously defined patients with HDA as those with 'rapidly evolving severe relapsing-remitting multiple sclerosis defined by 2 or more disabling relapses in one year, and with 1 or more Gadolinium-enhancing $(\mathrm{Gd}+)$ lesions on brain MRI or a significant increase in $\mathrm{T} 2$ lesion load as compared to a previous recent MRI) were further subgrouped [85-91]. New definitions were introduced, one being "high relapse activity" (HRA - patients with $\geqslant 2$ relapses during the year prior to study entry, whether on DMD treatment or not), the other being HRA+"disease activity on treatment" (HRA+ DAT patients with $\geqslant 2$ relapses during the year prior to study entry, whether on DMD treatment or not, PLUS patients with $\geqslant 1$ relapse during the year prior to study entry while on therapy with other DMDs and $\geqslant 1 \mathrm{~T} 1 \mathrm{Gd}+$ or $\geqslant 9 \mathrm{~T} 2$ lesions). The overall $3.5 \mathrm{mg} / \mathrm{kg}$ base population consisted of 437 participants, the HRA group had 131 patients, the non-HRA consisted of 306 patients, the HRA+DAT subgroup involved 149 patients, while the non-HRA+DAT subgroup comprised of 288 subjects. The ARR in the overall (treated with 3.5 $\mathrm{mg} / \mathrm{kg}$ cladribine, HRA+non-HRA) population was 0.35 ( $95 \%$ CI 0.31 to 0.39 ), in the HRA group it was 0.50 (95\% CI 0.41 to 0.60 ), in the non-HRA group 0.29 (95\% CI 0.24 to 0.34 ), in the HRA+DAT group 0.47 (95\% CI 0.40 to 0.57 ) in the non-HRA+DAT group 0.29 (95\% CI 0.24 to 0.34$)$. In the original study treatment with $3.5 \mathrm{mg} / \mathrm{kg}$ cladribine in comparison with placebo reduced the risk of 6-monthconfirmed EDSS worsening by $47 \%(\mathrm{HR}=0.53,95 \% \mathrm{CI}=$ 0.36 to $0.79, p=0.0016$ ). In the posthoc analysis then HRA and HRA+DAT patients were compared to non-HRA patients the risk reduction was even greater, $82 \%$ (interaction $\mathrm{p}$-value 0.0036 for HRA vs. non-HRA, and $\mathrm{p}=0.0037$ for HRA + DAT $v s$. non-HRA + DAT). The time for first qualifying relapse was also shorter in HRA and HRA+DAT patients than in non-HRA and non-HRA+DAT patients. Odds ratio assessment was also conducted to evaluate the probability of achieving NEDA state of the patients in the HRA and HRA+DAT groups. Odds ratios were $8.02,(95 \% \mathrm{CI}=3.93$ to $16.35 ; \mathrm{p}<0.0001)$ and $7.82(95 \% \mathrm{CI}=4.03$ to 15.19 ; $\mathrm{p}<0.0001$ ) respectively. MRI findings indicated that the relative risk for T2 active lesions, Gd-enhancing lesions, and combined unique lesions were low in all assessed subgroups. Overall safety data for the HRA and HRA+DAT subgroups did not differ from the data obtained from the overall study population. The analysis concluded that subjects with high disease activity responded better to treatment both clinically and radiologically than the overall study population [85].

Of the 1184 patients that have completed the CLARITY trial, 867 were enrolled in the CLARITY Extension study [92]. 61 patients who were not eligible were solely followed, the rest 806 patients were re-randomized or assigned to treatment if previously received placebo. Of the 806 treated patients, $738(91.6 \%)$ completed the 2-year trial. The sociodemographic and disease characteristics of patients enrolled were similar across all arms to the base trial's, with the exception that patients who had received placebo in the CLAR-
ITY study had higher disease activity than the rest of the population. The patients participating in the study were rerandomized. All patients taking placebo in CLARITY received a $3.5 \mathrm{mg} / \mathrm{kg}$ cumulative dosage of cladribine (PC 3.5 $\mathrm{mg} / \mathrm{kg}, \mathrm{n}=244$ ), patients taking $3.5 \mathrm{mg} / \mathrm{kg}$ in the original study either received placebo (CP $3.5 \mathrm{mg} / \mathrm{kg}, \mathrm{n}=98$ ) or treatment $(\mathrm{CC}$, cumulative dosage $7.0 \mathrm{mg} / \mathrm{kg}$ over the $2+2$ years, $\mathrm{n}=186$ ), patients treated with $5.25 \mathrm{mg} / \mathrm{kg}$ cladribine were either given placebo (CP $5.25 \mathrm{mg} / \mathrm{kg}, \mathrm{n}=92$ ) or cladribine in $3.5 \mathrm{mg} / \mathrm{kg}$ dosage (CC, $8.75 \mathrm{mg} / \mathrm{kg}$ cumulative dosage, $\mathrm{n}=186$ ). To assess the potential effect of temporal delay and incremental effect of treatment with cladribine for an extended duration and larger doses additional comparisons were conducted than in the original trial. The assessed and compared groups in the extensions were CP $3.5 \mathrm{mg} / \mathrm{kg}$ vs. PC $3.5 \mathrm{mg} / \mathrm{kg}$ (to investigate the effect of early versus late treatment with the same dosage), CC $7 \mathrm{mg} / \mathrm{kg} v s$. CP 3.5 $\mathrm{mg} / \mathrm{kg}$, CC $8.75 \mathrm{mg} / \mathrm{kg} v s$. CP $5.25 \mathrm{mg} / \mathrm{kg}$ (192 weeks of treatment vs. 96 weeks of treatment), and CC $7 \mathrm{mg} / \mathrm{kg}+\mathrm{CC}$ $8.75 \mathrm{mg} / \mathrm{kg}$ (combined data for patients who received treatment with cladribine tablets in CLARITY and CLARITY Extension) vs. CP $3.5 \mathrm{mg} / \mathrm{kg}+$ CP $5.25 \mathrm{mg} / \mathrm{kg}$ (combined data for placebo in Years 3 and 4) [92].

The primary and secondary clinical endpoints in the extension study were the same as in the pivotal trial. No MRI endpoints were specified in the extension study. Betweengroup analysis of the clinical efficacy endpoints (ARR, time to 3 months confirmed EDSS progression, the proportion of relapse-free patients) showed no significant differences between the evaluated treatment groups ( $p>0.05$ for all comparisons) [92].

The ARR reduction seen in the extension study was similar in all groups to that seen in the pivotal study, betweengroup comparison has proven no significant differences between treatment arms. Furthermore, there was no significant difference between treatment groups in time to first relapse [92]. The proportion of relapse-free patients approximately matched the magnitude seen in the treated arms of the CLARITY study and was roughly equivalent in all treated groups in the extension study. The only significant difference between the study groups was seen in the PC $3.5 \mathrm{mg} / \mathrm{kg}$ group $(\mathrm{n}=244)$, in which the proportion of relapse-free patients was $58.0 \%$ while on placebo, meanwhile it was $79.6 \%$ at the end of the extension study ( $<<0.0001)$, which was approximately equivalent to the values seen in other treatment arms [92]. Also, the proportion of patients who remained free of 3-month confirmed EDSS progression was similar across all treatment arms $(\sim 75 \%)$, however, it was slightly lower $(6.3 \%-13.3 \%)$ than the results seen in the original study ( $\sim 85 \%)$. Roughly $4 / 5^{\text {th }}$ of patients were free of relapses in the pivotal trial, who received $3.5 \mathrm{mg} / \mathrm{kg}$ cladribine, $75 \%$ of the patients were still free of relapses at the end of week 120 who were afterward randomized to placebo in the extension study (i.e. the CP $3.5 \mathrm{mg} / \mathrm{kg}$ treatment group) [92]. This indicates that treatment produced a clinical response, that was maintained for at least 2 years after treatment discontinuation [92]. At the end of the extension study, no evidence of disease rebound effect was seen in the groups which were rerandomized to placebo (from either treatment groups), after treatment with cladribine in the original study, a side effect 
Table 7. Baseline demographics and disease characteristics of treatment groups in the CLARITY Extension study. Data are shown as mean (standard deviation (SD)) unless stated otherwise.

\begin{tabular}{|c|c|c|c|c|c|}
\hline \multicolumn{6}{|c|}{ Clarity Extension } \\
\hline- & $3.5 \mathrm{mg} / \mathrm{kg}(\mathrm{n}=98)$ & $5.25 \mathrm{mg} / \mathrm{kg}(\mathrm{n}=92)$ & $7 \mathrm{mg} / \mathrm{kg}(\mathrm{n}=186)$ & $8.75 \mathrm{mg} / \mathrm{kg}(\mathrm{n}=186)$ & $\begin{array}{c}\text { PC } \\
3.5 \mathrm{mg} / \mathrm{kg}(\mathrm{n}=244)\end{array}$ \\
\hline Age & $40.7 \pm 10.7$ & $40.8 \pm 9.6$ & $40.6 \pm 10.5$ & $41.4 \pm 10.1$ & $41.6 \pm 9.6$ \\
\hline Females - no. (\%) & $67(68.4 \%)$ & $59(64.1 \%)$ & $124(66.7 \%)$ & $125(67.2 \%)$ & $156(63.9 \%)$ \\
\hline Weight - kg & $67.93 \pm 14.89$ & $70.53 \pm 15.16$ & $68.91 \pm 14.09$ & $68.56 \pm 14.01$ & $70.68 \pm 15.56$ \\
\hline Prior DMD within 3 month of study start & 0 & 0 & 0 & 0 & $3(1.2 \%)$ \\
\hline DMD between CLARITY and extension & 2 & 0 & 0 & 0 & 4 \\
\hline Relapses between CLARITY and extension & $9(9.2 \%)$ & $8(8.7 \%)$ & $17(9.1 \%)$ & $18(9.7 \% 9$ & $46(18.9 \%)$ \\
\hline $\mathrm{T} 1 \mathrm{Gd}+$ lesion volume $-\mathrm{mm} 3$ & $18.45(68.14)$ & $19.78(108.84)$ & $43.46(245.13)$ & $49.19(266.98)$ & $132.30(415.18)$ \\
\hline No. Of $\mathrm{T} 1$ hypointense lesions & $13.53(13.39)$ & $13.72(15.84)$ & $11.46(12.66)$ & $12.96(14.66)$ & $13.28(14.35)$ \\
\hline $\mathrm{T} 1$ hypointense lesion volume - $1000 \mathrm{~mm} 3$ & $2.39(3.15)$ & $3.50(7.47)$ & $1.95(2.68)$ & $2.37(3.66)$ & $2.31(3.97)$ \\
\hline $\mathrm{T} 2$ kesion volume - $1000 \mathrm{~mm} 3$ & $18.57(19.05)$ & $16.95(18.17)$ & $13.69(14.39)$ & $15.76(14.55)$ & $16.43(13.81)$ \\
\hline Mean gap between studies * - weeks & $41.16(26.13)$ & $41.19(35.86)$ & $42.08(25.37)$ & $39.97(23.89)$ & $41.99(27.47)$ \\
\hline $\begin{array}{c}\text { Median gap between studies * } \\
\text { - weeks (min, max) }\end{array}$ & $41.29(0.1 ; 116.0)$ & $43.07(0.3 ; 112.9)$ & $41.43(0.4 ; 115.3)$ & $39.50(0.9 ; 111.0)$ & $39.71(0.3 ; 118.0)$ \\
\hline
\end{tabular}

*The duration of time in weeks between the last visit date in the CLARITY study treatment period and the randomization date in the CLARITY Extension trial.

seen in other therapies with a direct effect on lymphocytes. The length of the treatment gap between the original and extension study (which varied between patients, but was roughly equivalent [median of 40.3 weeks] across all treatment groups) had no effect on the ARR, the proportion of relapse-free patients, time to first qualifying relapse, nor the time to 3-month confirmed EDSS progression. Nonetheless, when both studies were considered together treatment delay had a negative effect on the time to first qualifying relapse; the shortest time was seen in the PC $3.5 \mathrm{mg} / \mathrm{kg}$ treatment group. Similarly, when the same patient groups were reevaluated at the end of the extension study from the original trial there was no difference between the groups in the matter of ARR, except in the PC $3.5 \mathrm{mg} / \mathrm{kg}$ group. In this group, a significant reduction was seen in the ARR after treatment ( 0.26 in the original trial, receiving placebo, 0.10 in the extension study, $60.7 \%$ relative reduction, $\mathrm{p}<0.0001)$. This difference in ARR reduction is on par with the reduction seen in the original study between the placebo and $3.5 \mathrm{mg} / \mathrm{kg}$ treatment groups $(57.6 \%$ relative reduction, $\mathrm{p}<0.001)$ [92].

\subsubsection{Safety and Safety Management}

The safety and tolerability profile of cladribine has been established over several well-constructed studies and was shown to be consistent throughout these evaluations [93]. Through the CLARITY and CLARITY EXTENSION stud- ies, there was a relatively low proportion of discontinuation due to adverse or serious adverse events (AE, SAE) [38, 92]. Most of the AEs were categorized as mild or moderate and were distributed relatively evenly through the treatment groups $[92,94]$. The exception from this rule was the appearance of lymphopenia, however, it was expected considering cladribine's mechanism of action $[92,94]$. The most rapid and underlined reduction was observed in the CD19+ B-cell subtypes $[95,96]$. Also, it was shown, that the reduction of CD8+ T-cells was less severe and had a faster rate of recovery than CD4+ T-cells $[95,96]$.

The rate of infections was not higher in the cladribine treatment groups as compared to placebo in the CLARITY and CLARITY EXTENSION studies, with the exception of herpes zoster infections [38, 92-94].

The rate of malignancies was slightly higher in the treatment groups than in the placebo arm in the CLARITY study; throughout CLARITY EXTENSION there was no difference between the groups [38, 92, 93]. This observed increase in the rate of malignancy in the CLARITY study and the fact that only one pivotal phase III study was initially done were the primary reason the EMA refused to approve oral cladribine in 2011 [93]. However, since then data from the second phase III study (ORACLE) - a continuous data stream from the safety register - and the change in the administration schedule of cladribine when encountering seri- 
ous lymphopenia and also solid epidemiological data indicating that there is no increased risk for secondary malignancies has led to the approval of cladribine for RRMS on second resubmission [93].

There were 4 fatal cases during the study and 2 cases after withdrawal $[93,94]$. The 4 fatal cases during the study had no connection whatsoever to the treatment, just like 1 case of metastatic pancreatic carcinoma after withdrawal [93, 94]. Yet, 1 case, an acute cardiopulmonary arrest was linked to cladribine. A 21-years old woman experienced pancytopenia one week after a single course of cladribine 5.25 $\mathrm{mg} / \mathrm{kg}$. The patient was immediately withdrawn from the study. The second phase of pancytopenia was observed approximately 2 months after stopping the treatment; an X-ray performed that time, revealed bilateral alveolar-interstitial infiltrates. Bone marrow biopsy was performed, which confirmed "slight myelodysplasia". Five months after treatment the patient went through another period of pancytopenia, the chest X-ray performed at that time revealed the recurrence of the bilateral infiltration and bone-marrow biopsy confirmed myelodysplastic syndrome. The patient died 6 months after receiving one single course of cladribine $5.25 \mathrm{mg} / \mathrm{kg}$. The post-mortem diagnosis of tuberculosis was made, and it was proved that the disease was long-standing and has been already present at the time of the initiation of cladribine treatment [93, 94]. It was concluded that treatment with cladribine sped up the progression of an already present infection [93, 94].

Hence, the two most pivotal safety management issues are the constant monitoring of the patients' lymphocyte counts and screening for VZV infections and tuberculosis. Varicella negative patients must be inoculated prior to the initiation of therapy with cladribine, which must be postponed 4-6 weeks to allow the vaccination to take full effect [70]. If a patient's lymphocyte count drops below 500 cells/mm3 active monitoring for infections, particularly for herpes zoster should begin [70]. If a patient develops grade IV lymphopenia herpes prophylaxis according to local practice should be considered during the time of lymphopenia [70]. Every patient must be screened for latent tuberculosis before initiation of treatment (both in the first and second year) [70]. The commencement of treatment with cladribine should be delayed until the infection has been adequately treated [70].

Also, in light of cladribine's mechanism of action and its potential for aggravating infections, attenuated live vaccines are contraindicated during treatment and after until the patients' white blood cell counts reach normal levels [93].

For further, detailed information of the adverse and serious adverse events and side effects that have occurred during the pivotal and the extension study - which is beyond the scope of this review - can be found in separate articles devoted to the matter $[38,92,94]$.

\section{CONCLUSION}

As a conclusion, we can state that cladribine proved to be a highly effective treatment choice for RRMS. Furthermore, despite the pivotal study being terminated early, $3.5 \mathrm{mg} / \mathrm{kg}$ cladribine tablets proved to be effective in halting the conversion of CIS patients into definite MS and in the future cladribine could become a potent choice for first-line therapy. It is the first DMD for MS for which the mechanism of action targets both the T- and B-cells, thus taking into account the complex pathomechanism of the disease. In spite of this dual action, the safety profile of the drug is clearly good; with some easily managed precautions, serious adverse events can be avoided. It has some other clear advantages as well. It is an orally administered DMD, which can enhance the adherence of the patients. Also, it is administered through $2 \times 2$ short courses which can be an attractive choice over constant drug-taking or infusions; and patients do not need to be admitted to the hospital for the administration and requires no long observation periods in contrast to other therapies.

Yet there are two important limitations right now, which need to be taken seriously. Firstly, we do not have any data yet on the long-term effectiveness of cladribine, as these data are yet to be revealed. Secondly, a limitation stemming from the mentioned lack of data above, we do not have any clear information on how to proceed, if the $2 \times 2$ courses of the drug fail to be effective enough. More data is needed for the satisfactory answer on how and when to administer another course of cladribine in such an event, or how and when to potentially change to another DMD (and which) if cladribine fails to halt the progression of the disease.

\section{LIST OF ABBREVIATIONS}

\begin{tabular}{|c|c|c|}
\hline ADA & $=$ & Adenosine Deaminase \\
\hline $\mathrm{AE}$ & $=$ & Adverse Event \\
\hline AIF & $=$ & Apoptosis-Inducing Factor \\
\hline ARR & $=$ & Annualised Relapse Rate \\
\hline BBB & $=$ & Blood-Brain Barrier \\
\hline $\mathrm{BCR}$ & $=$ & B-Cell Receptor \\
\hline BVL & $=$ & Brain Volume Loss \\
\hline $\mathrm{CC}$ & $=$ & Cladribine Tablets in Both Studies \\
\hline CDK-2 & $=$ & Cyclin-Dependent Kinase 2 \\
\hline $\mathrm{CI}$ & $=$ & Confidence Interval \\
\hline CIS & $=$ & Clinically Isolated Syndrome \\
\hline CNS & $=$ & Central Nervous System \\
\hline $\mathrm{CP}$ & $=$ & Cladribine then Placebo \\
\hline CSF & $=$ & Cerebrospinal Fluid \\
\hline 2-CdADP & $=$ & $\begin{array}{l}\text { 2-Chloro-2'-deoxy- } \beta \text {-D-adenosine diphos- } \\
\text { phate }\end{array}$ \\
\hline 2-CdAMP & $=$ & $\begin{array}{l}\text { 2-Chloro-2'-deoxy- } ß \text {-D-adenosine mono- } \\
\text { phosphate }\end{array}$ \\
\hline 2-CdATP & $=$ & $\begin{array}{l}\text { 2-Chloro-2'-deoxy- } \beta \text {-D-adenosine tri- } \\
\text { hosphate }\end{array}$ \\
\hline DA & $=$ & Deoxyadenosine \\
\hline
\end{tabular}




$\begin{array}{llll}\text { dADP } & =\text { Deoxy-Adenosine-Diphosphate } & \text { PBVC/y } & =\text { Annualized Percentage Brain volUme } \\ \text { Change Rate }\end{array}$

EMA $=$ European Medicines Agency

$\mathrm{Gd}=$ Gadolinimum

$\mathrm{HBcAB}=$ Hepatitis B Virus Core Antibody

HBsAg = Hepatitis B Virus Surface Antigen

HBV $\quad=$ Heptatitis B Virus

$\mathrm{HCV}=$ Hepatitis $\mathrm{C}$ Virus

HDA $=$ High Disease Activity

HIV $\quad=$ Human Immunodeficiency Virus

HPV $=$ Human Papilloma Virus

HR $=$ Hazard Ratio

HRA $=$ High Relapse Activity

HspB5 $=$ Small Heat Shock Protein $\alpha$ B-crystallin

IFN- $\gamma=$ Inferferon Gamma

$\mathrm{JCV}=\mathrm{JC}$ Virus

MBP $=$ Myelin Basic Protein

MHC-II $=$ Major Histocompatibility Complex II

MOG = Myelin Oligodendrocyte Glycoprotein

MRI = Magnetic Resonance Imaging

MS $\quad=$ Multiple Sclerosis

mtPTP $=$ Mitochondrial Permeability Transition Pore

NEDA $=$ No Evidence of Disease Activity

NGF-beta $=$ Nerve Growth Factor Beta

OGP $=$ Oligoclonal Gammopathy

[4] Zsiros, V.; Fricska-Nagy, Z.; Füvesi, J.; Kincses, Z.T.; Langane, E.; Paulik, E.; Vécsei, L.; Bencsik, K. Prevalence of multiple sclerosis in Csongrád County, Hungary. Acta Neurol. Scand., 2014, 130(5), $277-282$.

[http://dx.doi.org/10.1111/ane.12219] [PMID: 24611546]

PARP $\quad=$ Poly-ADP-Ribose-Polymerase

[5] Bencsik, K.; Sandi, D.; Biernacki, T.; Kincses, Z.; Füvesi, J.; Fricska-Nagy, Z.; Vécsei, L. [The Multiple Sclerosis Registry of Sze- 
ged]. Ideggyogy. Sz., 2017, 70(9-10), 301-306. [The Multiple Sclerosis Registry of Szeged].

[http://dx.doi.org/10.18071/isz.70.0301] [PMID: 29870621]

[6] Sandi, D.; Zsiros, V.; Füvesi, J.; Kincses, Z.T.; Fricska-Nagy, Z.; Lencsés, G.; Vécsei, L.; Bencsik, K. Mortality in Hungarian patients with multiple sclerosis between 1993 and 2013. J. Neurol. Sci., 2016, 367, 329-332.

[http://dx.doi.org/10.1016/j.jns.2016.06.035] [PMID: 27423613]

[7] Lublin, F.D.; Reingold, S.C. Defining the clinical course of multiple sclerosis: results of an international survey. Neurology, 1996, 46(4), 907-911.

[http://dx.doi.org/10.1212/WNL.46.4.907] [PMID: 8780061]

[8] Polman, C.H.; Reingold, S.C.; Banwell, B.; Clanet, M.; Cohen, J.A.; Filippi, M.; Fujihara, K.; Havrdova, E.; Hutchinson, M.; Kappos, L.; Lublin, F.D.; Montalban, X.; O’Connor, P.; SandbergWollheim, M.; Thompson, A.J.; Waubant, E.; Weinshenker, B.; Wolinsky, J.S. Diagnostic criteria for multiple sclerosis: 2010 revisions to the McDonald criteria. Ann. Neurol., 2011, 69(2), 292-302. [http://dx.doi.org/10.1002/ana.22366] [PMID: 21387374]

[9] Thompson, A.J.; Banwell, B.L.; Barkhof, F.; Carroll, W.M.; Coetzee, T.; Comi, G.; Correale, J.; Fazekas, F.; Filippi, M.; Freedman, M.S.; Fujihara, K.; Galetta, S.L.; Hartung, H.P.; Kappos, L.; Lublin, F.D.; Marrie, R.A.; Miller, A.E.; Miller, D.H.; Montalban, X.; Mowry, E.M.; Sorensen, P.S.; Tintoré, M.; Traboulsee, A.L.; Trojano, M.; Uitdehaag, B.M.J.; Vukusic, S.; Waubant, E.; Weinshenker, B.G.; Reingold, S.C.; Cohen, J.A. Diagnosis of multiple sclerosis: 2017 revisions of the McDonald criteria. Lancet Neurol., 2018, $17(2), 162-173$.

[http://dx.doi.org/10.1016/S1474-4422(17)30470-2] [PMID: 29275977]

[10] Lublin, F.D.; Reingold, S.C.; Cohen, J.A.; Cutter, G.R.; Sørensen, P.S.; Thompson, A.J.; Wolinsky, J.S.; Balcer, L.J.; Banwell, B.; Barkhof, F.; Bebo, B., Jr; Calabresi, P.A.; Clanet, M.; Comi, G.; Fox, R.J.; Freedman, M.S.; Goodman, A.D.; Inglese, M.; Kappos, L.; Kieseier, B.C.; Lincoln, J.A.; Lubetzki, C.; Miller, A.E.; Montalban, X.; O’Connor, P.W.; Petkau, J.; Pozzilli, C.; Rudick, R.A.; Sormani, M.P.; Stüve, O.; Waubant, E.; Polman, C.H. Defining the clinical course of multiple sclerosis: the 2013 revisions. Neurology, 2014, 83(3), 278-286.

[http://dx.doi.org/10.1212/WNL.0000000000000560] [PMID: 24871874]

[11] Lassmann, H. Pathology and disease mechanisms in different stages of multiple sclerosis. J. Neurol. Sci., 2013, 333(1-2), 1-4.

[http://dx.doi.org/10.1016/j.jns.2013.05.010] [PMID: 23735777]

[12] Stys, P.K.; Zamponi, G.W.; van Minnen, J.; Geurts, J.J. Will the real multiple sclerosis please stand up? Nat. Rev. Neurosci., 2012, 13(7), 507-514.

[http://dx.doi.org/10.1038/nrn3275] [PMID: 22714021]

[13] Yadav, S.K.; Mindur, J.E.; Ito, K.; Dhib-Jalbut, S. Advances in the immunopathogenesis of multiple sclerosis. Curr. Opin. Neurol., 2015, 28(3), 206-219.

[http://dx.doi.org/10.1097/WCO.0000000000000205]

[PMID: 25887768]

[14] Miljković, D.; Spasojević, I. Multiple sclerosis: molecular mechanisms and therapeutic opportunities. Antioxid. Redox Signal., 2013, 19(18), 2286-2334.

[http://dx.doi.org/10.1089/ars.2012.5068] [PMID: 23473637]

[15] Kebir, H.; Ifergan, I.; Alvarez, J.I.; Bernard, M.; Poirier, J.; Arbour, N.; Duquette, P.; Prat, A. Preferential recruitment of interferongamma-expressing TH17 cells in multiple sclerosis. Ann. Neurol., 2009, 66(3), 390-402.

[http://dx.doi.org/10.1002/ana.21748] [PMID: 19810097]

[16] Kleinewietfeld, M.; Hafler, D.A. Regulatory T cells in autoimmune neuroinflammation. Immunol. Rev., 2014, 259(1), 231-244. [http://dx.doi.org/10.1111/imr.12169] [PMID: 24712469]

[17] Lucchinetti, C.; Brück, W.; Parisi, J.; Scheithauer, B.; Rodriguez, M.; Lassmann, H. Heterogeneity of multiple sclerosis lesions: implications for the pathogenesis of demyelination. Ann. Neurol., 2000, 47(6), 707-717.

[http://dx.doi.org/10.1002/1531-8249(200006)47:6<707::AIDANA3>3.0.CO;2-Q] [PMID: 10852536]

[18] Constantinescu, C.S.; Hilliard, B.; Ventura, E.; Wysocka, M.; Showe, L.; Lavi, E.; Fujioka, T.; Scott, P.; Trinchieri, G.; Rostami, A. Modulation of susceptibility and resistance to an autoimmune model of multiple sclerosis in prototypically susceptible and re- sistant strains by neutralization of interleukin-12 and interleukin-4 respectively. Clin. Immunol., 2001, 98(1), 23-30.

[http://dx.doi.org/10.1006/clim.2000.4944] [PMID: 11141323]

[19] Voskuhl, R.R.; Martin, R.; Bergman, C.; Dalal, M.; Ruddle, N.H.; McFarland, H.F. T helper 1 (Th1) functional phenotype of human myelin basic protein-specific T lymphocytes. Autoimmunity, 1993, 15(2), 137-143.

[http://dx.doi.org/10.3109/08916939309043888] [PMID: 7692995]

[20] Bettelli, E.; Carrier, Y.; Gao, W.; Korn, T.; Strom, T.B.; Oukka M.; Weiner, H.L.; Kuchroo, V.K. Reciprocal developmental pathways for the generation of pathogenic effector $\mathrm{TH} 17$ and regulatory T cells. Nature, 2006, 441(7090), 235-238.

[http://dx.doi.org/10.1038/nature04753] [PMID: 16648838]

[21] Edwards, L.J.; Robins, R.A.; Constantinescu, C.S. Th17/Th1 phenotype in demyelinating disease. Cytokine, 2010, 50(1), 19-23. [http://dx.doi.org/10.1016/j.cyto.2009.12.003] [PMID: 20045653]

[22] Nyirenda, M.H.; Sanvito, L.; Darlington, P.J.; O’Brien, K.; Zhang, G.X.; Constantinescu, C.S.; Bar-Or, A.; Gran, B. TLR2 stimulation drives human naive and effector regulatory $\mathrm{T}$ cells into a Th17-like phenotype with reduced suppressive function. J. Immunol., 2011, $187(5), 2278-2290$.

[http://dx.doi.org/10.4049/jimmunol.1003715] [PMID: 21775683]

[23] Sinha, S.; Itani, F.R.; Karandikar, N.J. Immune regulation of multiple sclerosis by CD8+ T cells. Immunol. Res., 2014, 59(1-3), 254265.

[http://dx.doi.org/10.1007/s12026-014-8529-9] [PMID: 24845461]

[24] Lehmann-Horn, K.; Kinzel, S.; Weber, M.S. Deciphering the Role of B Cells in Multiple Sclerosis-Towards Specific Targeting of Pathogenic Function. Int. J. Mol. Sci., 2017, $18(10)$ E2048

[http://dx.doi.org/10.3390/ijms 18102048] [PMID: 28946620]

[25] Weber, M.S.; Hemmer, B.; Cepok, S. The role of antibodies in multiple sclerosis. Biochim. Biophys. Acta, 2011, 1812(2), 239-245. [http://dx.doi.org/10.1016/j.bbadis.2010.06.009] [PMID: 20600871]

[26] Reiber, H.; Ungefehr, S.; Jacobi, C. The intrathecal, polyspecific and oligoclonal immune response in multiple sclerosis. Mult. Scler., 1998, 4(3), 111-117.

[http://dx.doi.org/10.1177/135245859800400304] [PMID: 9762657]

[27] Mathias, A.; Perriard, G.; Canales, M.; Soneson, C.; Delorenzi, M.; Schluep, M.; Du Pasquier, R.A. Increased ex vivo antigen presentation profile of B cells in multiple sclerosis. Mult. Scler., 2017, 23(6), 802-809.

[http://dx.doi.org/10.1177/1352458516664210] [PMID: 27503907]

[28] Harp, C.T.; Ireland, S.; Davis, L.S.; Remington, G.; Cassidy, B.; Cravens, P.D.; Stuve, O.; Lovett-Racke, A.E.; Eagar, T.N.; Greenberg, B.M.; Racke, M.K.; Cowell, L.G.; Karandikar, N.J.; Frohman, E.M.; Monson, N.L. Memory B cells from a subset of treatment-naïve relapsing-remitting multiple sclerosis patients elicit CD4(+) T-cell proliferation and IFN- $\gamma$ production in response to myelin basic protein and myelin oligodendrocyte glycoprotein. Eur. J. Immunol., 2010, 40(10), 2942-2956.

[http://dx.doi.org/10.1002/eji.201040516] [PMID: 20812237]

[29] Lanzavecchia, A. Antigen-specific interaction between T and B cells. Nature, 1985, 314(6011), 537-539.

[http://dx.doi.org/10.1038/314537a0] [PMID: 3157869]

[30] Pöllinger, B.; Krishnamoorthy, G.; Berer, K.; Lassmann, H.; Bösl, M.R.; Dunn, R.; Domingues, H.S.; Holz, A.; Kurschus, F.C.; Wekerle, H. Spontaneous relapsing-remitting EAE in the SJL/J mouse: MOG-reactive transgenic T cells recruit endogenous MOG-specific B cells. J. Exp. Med., 2009, 206(6), 1303-1316.

[http://dx.doi.org/10.1084/jem.20090299] [PMID: 19487416]

[31] Krishnamoorthy, G.; Lassmann, H.; Wekerle, H.; Holz, A. Spontaneous opticospinal encephalomyelitis in a double-transgenic mouse model of autoimmune $\mathrm{T}$ cell/B cell cooperation. J. Clin. Invest., 2006, $116(9), 2385-2392$.

[http://dx.doi.org/10.1172/JCI28330] [PMID: 16955140]

[32] Molnarfi, N.; Schulze-Topphoff, U.; Weber, M.S.; Patarroyo, J.C.; Prod'homme, T.; Varrin-Doyer, M.; Shetty, A.; Linington, C.; Slavin, A.J.; Hidalgo, J.; Jenne, D.E.; Wekerle, H.; Sobel, R.A.; Bernard, C.C.; Shlomchik, M.J.; Zamvil, S.S. MHC class IIdependent B cell APC function is required for induction of CNS autoimmunity independent of myelin-specific antibodies. J. Exp. Med., 2013, 210(13), 2921-2937.

[http://dx.doi.org/10.1084/jem.20130699] [PMID: 24323356] 
[33] Barr, T.A.; Shen, P.; Brown, S.; Lampropoulou, V.; Roch, T.; Lawrie, S.; Fan, B.; O'Connor, R.A.; Anderton, S.M.; Bar-Or, A.; Fillatreau, S.; Gray, D. B cell depletion therapy ameliorates autoimmune disease through ablation of IL-6-producing B cells. J. Exp. Med., 2012, 209(5), 1001-1010.

[http://dx.doi.org/10.1084/jem.20111675] [PMID: 22547654]

[34] Bjarnadóttir, K.; Benkhoucha, M.; Merkler, D.; Weber, M.S.; Payne, N.L.; Bernard, C.C.A.; Molnarfi, N.; Lalive, P.H. B cellderived transforming growth factor- $\beta 1$ expression limits the induction phase of autoimmune neuroinflammation. Sci. Rep., 2016, 6, 34594.

[http://dx.doi.org/10.1038/srep34594] [PMID: 27708418]

[35] Major, E.O.; Nath, A. A link between long-term natalizumab dosing in MS and PML: Putting the puzzle together. Neurol. Neuroimmunol. Neuroinflamm., 2016, 3(3)e235

[http://dx.doi.org/10.1212/NXI.0000000000000235] [PMID: 27213175]

[36] Giovannoni, G.; Kappos, L.; Gold, R.; Khatri, B.O.; Selmaj, K.; Umans, K.; Greenberg, S.J.; Sweetser, M.; Elkins, J.; McCroskery, P. Safety and tolerability profile of daclizumab in patients with relapsing-remitting multiple sclerosis: An integrated analysis of clinical studies. Mult. Scler. Relat. Disord., 2016, 9, 36-46.

[http://dx.doi.org/10.1016/j.msard.2016.05.010] [PMID: 27645341]

[37] Holmøy, T.; von der Lippe, H.; Leegaard, T.M. Listeria monocytogenes infection associated with alemtuzumab - - a case for better preventive strategies. BMC Neurol., 2017, 17(1), 65.

[http://dx.doi.org/10.1186/s12883-017-0848-8] [PMID: 28376817]

[38] Giovannoni, G.; Comi, G.; Cook, S.; Rammohan, K.; Rieckmann, P.; Soelberg Sørensen, P.; Vermersch, P.; Chang, P.; Hamlett, A.; Musch, B.; Greenberg, S.J. A placebo-controlled trial of oral cladribine for relapsing multiple sclerosis. N. Engl. J. Med., 2010, 362(5), 416-426.

[http://dx.doi.org/10.1056/NEJMoa0902533] [PMID: 20089960]

[39] Beutler, E. Cladribine (2-chlorodeoxyadenosine). Lancet, 1992, 340(8825), 952-956.

[http://dx.doi.org/10.1016/0140-6736(92)92826-2]

[PMID: 1357355]

[40] Piro, L.D.; Carrera, C.J.; Carson, D.A.; Beutler, E. Lasting remissions in hairy-cell leukemia induced by a single infusion of 2chlorodeoxyadenosine. N. Engl. J. Med., 1990, 322(16), 11171121.

[http://dx.doi.org/10.1056/NEJM199004193221605] [PMID: 1969613]

[41] Lauria, F.; Cencini, E.; Forconi, F. Alternative methods of cladribine administration. Leuk. Lymphoma, 2011, 52(Suppl. 2), 34-37.

[http://dx.doi.org/10.3109/10428194.2011.570395] [PMID: 21504286]

[42] Johnston, J.B. Mechanism of action of pentostatin and cladribine in hairy cell leukemia. Leuk. Lymphoma, 2011, 52(Suppl. 2), 43-45. [http://dx.doi.org/10.3109/10428194.2011.570394] [PMID: 21463108]

[43] Van den Neste, E.; Cardoen, S.; Offner, F.; Bontemps, F. Old and new insights into the mechanisms of action of two nucleoside analogs active in lymphoid malignancies: fludarabine and cladribine (review). Int. J. Oncol., 2005, 27(4), 1113-1124. [review]. [http://dx.doi.org/10.3892/ijo.27.4.1113] [PMID: 16142330]

[44] Wataya, Y.; Hirota, Y.; Hiramoto-Yoshioka, A.; Tanaka, S.; Otani, T.; Minowada, J.; Matsuda, A.; Ueda, T. The mechanism of 2chlorodeoxyadenosine-induced cell death. Adv. Exp. Med. Biol., 1989, 253B, 227-234.

[http://dx.doi.org/10.1007/978-1-4684-5676-9_34] [PMID: 2575349]

[45] Griffig, J.; Koob, R.; Blakley, R.L. Mechanisms of inhibition of DNA synthesis by 2-chlorodeoxyadenosine in human lymphoblastic cells. Cancer Res., 1989, 49 (24 Pt 1), 6923-6928. [PMID: 2573423]

[46] Van Den Neste, E.; Cardoen, S.; Husson, B.; Rosier, J.F.; Delacauw, A.; Ferrant, A.; Van den Berghe, G.; Bontemps, F. 2-Chloro2 -deoxyadenosine inhibits DNA repair synthesis and potentiates UVC cytotoxicity in chronic lymphocytic leukemia B lymphocytes. Leukemia, 2002, 16(1), 36-43.

[http://dx.doi.org/10.1038/sj.leu.2402331] [PMID: 11840261]

[47] Chunduru, S.K.; Appleman, J.R.; Blakley, R.L. Activity of human DNA polymerases alpha and beta with 2-chloro-2'-deoxyadenosine 5'-triphosphate as a substrate and quantitative effects of incorporation on chain extension. Arch. Biochem. Biophys., 1993, 302(1), 19-30.

[http://dx.doi.org/10.1006/abbi.1993.1175] [PMID: 8470896]

[48] Parker, W.B.; Bapat, A.R.; Shen, J.X.; Townsend, A.J.; Cheng, Y.C. Interaction of 2-halogenated dATP analogs $(\mathrm{F}, \mathrm{Cl}$, and $\mathrm{Br})$ with human DNA polymerases, DNA primase, and ribonucleotide reductase. Mol. Pharmacol., 1988, 34(4), 485-491.

[PMID: 3050447]

[49] Hentosh, P.; Koob, R.; Blakley, R.L. Incorporation of 2-halogeno2'-deoxyadenosine 5-triphosphates into DNA during replication by human polymerases alpha and beta. J. Biol. Chem., 1990, 265(7), 4033-4040.

[PMID: 2303492]

[50] Richardson, D.S.; Allen, P.D.; Kelsey, S.M.; Newland, A.C. Effects of PARP inhibition on drug and Fas-induced apoptosis in leukaemic cells. Adv. Exp. Med. Biol., 1999, 457, 267-279.

[http://dx.doi.org/10.1007/978-1-4615-4811-9 29]

[PMID: 10500802]

[51] Pettitt, A.R.; Sherrington, P.D.; Cawley, J.C. Role of poly(ADPribosyl)ation in the killing of chronic lymphocytic leukemia cells by purine analogues. Cancer Res., 2000, 60(15), 4187-4193. [PMID: 10945628]

[52] Galmarini, C.M.; Voorzanger, N.; Falette, N.; Jordheim, L.; Cros, E.; Puisieux, A.; Dumontet, C. Influence of p53 and p21(WAF1) expression on sensitivity of cancer cells to cladribine. Biochem. Pharmacol., 2003, 65(1), 121-129.

[http://dx.doi.org/10.1016/S0006-2952(02)01448-X] [PMID: 12473386]

[53] Achanta, G.; Pelicano, H.; Feng, L.; Plunkett, W.; Huang, P. Interaction of p53 and DNA-PK in response to nucleoside analogues: potential role as a sensor complex for DNA damage. Cancer Res., 2001, 61(24), 8723-8729.

[PMID: 11751391]

[54] Chow, K.U.; Nowak, D.; Boehrer, S.; Ruthardt, M.; Knau, A.; Hoelzer, D.; Mitrou, P.S.; Weidmann, E. Synergistic effects of chemotherapeutic drugs in lymphoma cells are associated with down-regulation of inhibitor of apoptosis proteins (IAPs), prostateapoptosis-response-gene 4 (Par-4), death-associated protein (Daxx) and with enforced caspase activation. Biochem. Pharmacol., 2003, 66(5), 711-724.

[http://dx.doi.org/10.1016/S0006-2952(03)00410-6] [PMID: 12948851]

[55] Borner, M.M.; Joncourt, F.; Hotz, M.A. Similarity of apoptosis induction by 2-chlorodeoxyadenosine and cisplatin in human mononuclear blood cells. Br. J. Cancer, 1997, 76(11), 1448-1454. [http://dx.doi.org/10.1038/bjc.1997.577] [PMID: 9400941]

[56] Szondy, Z. The 2-chlorodeoxyadenosine-induced cell death signalling pathway in human thymocytes is different from that induced by 2-chloroadenosine. Biochem. J., 1995, 311(Pt 2), 585-588. [http://dx.doi.org/10.1042/bj3110585] [PMID: 7487899]

[57] Mackus, W.J.; Kater, A.P.; Grummels, A.; Evers, L.M.; Hooijbrink, B.; Kramer, M.H.; Castro, J.E.; Kipps, T.J.; van Lier, R.A.; van Oers, M.H.; Eldering, E. Chronic lymphocytic leukemia cells display p53-dependent drug-induced Puma upregulation. Leukemia, 2005, 19(3), 427-434.

[http://dx.doi.org/10.1038/sj.leu.2403623] [PMID: 15674362]

[58] Adams, J.M. Ways of dying: multiple pathways to apoptosis Genes Dev., 2003, 17(20), 2481-2495.

[http://dx.doi.org/10.1101/gad.1126903] [PMID: 14561771]

[59] Gartenhaus, R.B.; Wang, P.; Hoffman, M.; Janson, D.; Rai, K.R. The induction of p53 and WAF1/CIP1 in chronic lymphocytic leukemia cells treated with 2-chlorodeoxyadenosine. J. Mol. Med. (Berl.), 1996, 74(3), 143-147.

[http://dx.doi.org/10.1007/BF01575446] [PMID: 8846164]

[60] Bellosillo, B.; Villamor, N.; López-Guillermo, A.; Marcé, S.; Bosch, F.; Campo, E.; Montserrat, E.; Colomer, D. Spontaneous and drug-induced apoptosis is mediated by conformational changes of Bax and Bak in B-cell chronic lymphocytic leukemia. Blood, 2002, 100(5), 1810-1816.

[http://dx.doi.org/10.1182/blood-2001-12-0327] [PMID: 12176904]

[61] Dewson, G.; Snowden, R.T.; Almond, J.B.; Dyer, M.J.; Cohen, G.M. Conformational change and mitochondrial translocation of 
Bax accompany proteasome inhibitor-induced apoptosis of chronic lymphocytic leukemic cells. Oncogene, 2003, 22(17), 2643-2654. [http://dx.doi.org/10.1038/sj.onc.1206326] [PMID: 12730678]

[62] Johnston, J.B.; Daeninck, P.; Verburg, L.; Lee, K.; Williams, G.; Israels, L.G.; Mowat, M.R.; Begleiter, A. P53, MDM-2, BAX and BCL-2 and drug resistance in chronic lymphocytic leukemia. Leuk. Lymphoma, 1997, 26(5-6), 435-449.

[http://dx.doi.org/10.3109/10428199709050881] [PMID: 9389352]

[63] Nomura, Y.; Inanami, O.; Takahashi, K.; Matsuda, A.; Kuwabara, M. 2-Chloro-2'-deoxyadenosine induces apoptosis through the Fas/Fas ligand pathway in human leukemia cell line MOLT-4. Leukemia, 2000, 14(2), 299-306. [http://dx.doi.org/10.1038/sj.leu.2401649] [PMID: 10673748]

[64] Marzo, I.; Pérez-Galán, P.; Giraldo, P.; Rubio-Félix, D.; Anel, A.; Naval, J. Cladribine induces apoptosis in human leukaemia cells by caspase-dependent and -independent pathways acting on mitochondria. Biochem. J., 2001, 359(Pt 3), 537-546.

[http://dx.doi.org/10.1042/bj3590537] [PMID: 11672427]

[65] Sampath, D.; Plunkett, W. The role of c-Jun kinase in the apoptotic response to nucleoside analogue-induced DNA damage. Cancer Res., 2000, 60(22), 6408-6415.

[PMID: 11103806]

[66] Friesen, C.; Herr, I.; Krammer, P.H.; Debatin, K.M. Involvement of the CD95 (APO-1/FAS) receptor/ligand system in drug-induced apoptosis in leukemia cells. Nat. Med., 1996, 2(5), 574-577.

[http://dx.doi.org/10.1038/nm0596-574] [PMID: 8616718]

[67] Korsen, M.; Bragado Alonso, S.; Peix, L.; Bröker, B.M.; Dressel, A. Cladribine Exposure Results in a Sustained Modulation of the Cytokine Response in Human Peripheral Blood Mononuclear Cells. PLoS One, 2015, 10(6)e 0129182

[http://dx.doi.org/10.1371/journal.pone.0129182] [PMID: 26086440]

[68] Liliemark, J. The clinical pharmacokinetics of cladribine. Clin. Pharmacokinet., 1997, 32(2), 120-131.

[http://dx.doi.org/10.2165/00003088-199732020-00003] [PMID: 9068927]

[69] Savic, R.M.; Novakovic, A.M.; Ekblom, M.; Munafo, A.; Karlsson, M.O. Population Pharmacokinetics of Cladribine in Patients with Multiple Sclerosis. Clin. Pharmacokinet., 2017, 56(10), 1245-1253. [http://dx.doi.org/10.1007/s40262-017-0516-6] [PMID: 28255849]

[70] European Medicinal Agency. Human Medicines., http://www.ema.europa.eu/docs/en_GB/document_library/EPAR_Product Information/human/004230/WC500234561.pdf2018.

[71] 2017. Mult. Scler., 2018, 24(3), 368-423.

[http://dx.doi.org/10.1177/1352458517751792]

[PMID: 29347859]

[72] European Medicinal Agency. Human Medicines., https://www.ema.europa.eu/en/documents/productinformation/mavenclad-epar-product-information_en.pdf2019.

[73] European Medicinal Agency. Human Medicines., https://www.ema.europa.eu/en/documents/productinformation/ocrevus-epar-product-information en.pdf2019.

[74] European Medicinal Agency. Human Medicines., https://www.ema.europa.eu/en/documents/productinformation/tysabri-epar-product-information_en.pdf2019.

[75] European Medicinal Agency. Human Medicines., https://www.ema.europa.eu/en/documents/productinformation/gilenya-epar-product-information_en.pdf2019.

[76] European Medicinal Agency. Human Medicines., https://www.ema.europa.eu/en/documents/productinformation/lemtrada-epar-product-information en.pdf2019.

[77] European Medicinal Agency. Human Medicines., https://www.ema.europa.eu/en/documents/productinformation/tecfidera-epar-product-information_en.pdf2019.

[78] European Medicinal Agency. Human Medicines., https://www.ema.europa.eu/en/documents/productinformation/aubagio-epar-product-information_en.pdf2019.

[79] Fazekas, F.; Barkhof, F.; Filippi, M.; Grossman, R.I.; Li, D.K.; McDonald, W.I.; McFarland, H.F.; Paty, D.W.; Simon, J.H.; Wolinsky, J.S.; Miller, D.H. The contribution of magnetic resonance imaging to the diagnosis of multiple sclerosis. Neurology, 1999, 53(3), 448-456.

[http://dx.doi.org/10.1212/WNL.53.3.448] [PMID: 10449103]
[80] Kurtzke, J.F. Rating neurologic impairment in multiple sclerosis: an expanded disability status scale (EDSS). Neurology, 1983, 33(11), 1444-1452.

[http://dx.doi.org/10.1212/WNL.33.11.1444] [PMID: 6685237]

[81] De Stefano, N.; Airas, L.; Grigoriadis, N.; Mattle, H.P.; O’Riordan, J.; Oreja-Guevara, C.; Sellebjerg, F.; Stankoff, B.; Walczak, A.; Wiendl, H.; Kieseier, B.C. Clinical relevance of brain volume measures in multiple sclerosis. CNS Drugs, 2014, 28(2), 147-156. [http://dx.doi.org/10.1007/s40263-014-0140-z] [PMID: 24446248]

[82] De Stefano, N.; Giorgio, A.; Battaglini, M.; De Leucio, A.; Hicking, C.; Dangond, F.; Giovannoni, G.; Sormani, M.P. Reduced brain atrophy rates are associated with lower risk of disability progression in patients with relapsing multiple sclerosis treated with cladribine tablets. Mult. Scler., 2018, 24(2), 222-226.

[http://dx.doi.org/10.1177/1352458517690269] [PMID: 28140753]

[83] Giovannoni, G.; Turner, B.; Gnanapavan, S.; Offiah, C.; Schmierer, K.; Marta, M. Is it time to target no evident disease activity (NEDA) in multiple sclerosis? Mult. Scler. Relat. Disord., 2015, 4(4), 329-333.

[http://dx.doi.org/10.1016/j.msard.2015.04.006] [PMID: 26195051]

[84] Giovannoni, G.; Cook, S.; Rammohan, K.; Rieckmann, P.; Sørensen, P.S.; Vermersch, P.; Hamlett, A.; Viglietta, V.; Greenberg, S Sustained disease-activity-free status in patients with relapsingremitting multiple sclerosis treated with cladribine tablets in the CLARITY study: a post-hoc and subgroup analysis. Lancet $\mathrm{Neu}$ rol., 2011, 10(4), 329-337.

[http://dx.doi.org/10.1016/S1474-4422(11)70023-0]

[PMID: 21397565]

[85] Giovannoni, G.; Soelberg Sorensen, P.; Cook, S. Efficacy of Cladribine Tablets in high disease activity subgroups of patients with relapsing multiple sclerosis: A post hoc analysis of the CLARITY study. Mult. Scler., 2018, ••1352458518771875 [PMID: 29716436]

[86] Bermel, R.A.; You, X.; Foulds, P.; Hyde, R.; Simon, J.H.; Fisher, E.; Rudick, R.A. Predictors of long-term outcome in multiple sclerosis patients treated with interferon $\beta$. Ann. Neurol., 2013, 73(1), 95-103.

[http://dx.doi.org/10.1002/ana.23758] [PMID: 23378325]

[87] Dobson, R.; Rudick, R.A.; Turner, B.; Schmierer, K.; Giovannoni, G. Assessing treatment response to interferon- $\beta$ : is there a role for MRI? Neurology, 2014, 82(3), 248-254.

[http://dx.doi.org/10.1212/WNL.0000000000000036] [PMID: 24336144]

[88] Río, J.; Castilló, J.; Rovira, A.; Tintoré, M.; Sastre-Garriga, J.; Horga, A.; Nos, C.; Comabella, M.; Aymerich, X.; Montalbán, X. Measures in the first year of therapy predict the response to interferon beta in MS. Mult. Scler., 2009, 15(7), 848-853.

[http://dx.doi.org/10.1177/1352458509104591] [PMID: 19542263]

[89] Río, J.; Rovira, A.; Tintoré, M.; Sastre-Garriga, J.; Castilló, J.; Auger, C.; Nos, C.; Comabella, M.; Tur, C.; Vidal, Á.; Montalbán, $\mathrm{X}$. Evaluating the response to glatiramer acetate in relapsingremitting multiple sclerosis (RRMS) patients. Mult. Scler., 2014, 20(12), 1602-1608.

[http://dx.doi.org/10.1177/1352458514527863] [PMID: 24622350]

[90] Río, J.; Ruiz-Peña, J.L. Short-term suboptimal response criteria for predicting long-term non-response to first-line disease modifying therapies in multiple sclerosis: A systematic review and metaanalysis. J. Neurol. Sci., 2016, 361, 158-167. [http://dx.doi.org/10.1016/j.jns.2015.12.043] [PMID: 26810535]

[91] Prosperini, L.; Mancinelli, C.R.; De Giglio, L.; De Angelis, F.; Barletta, V.; Pozzilli, C. Interferon beta failure predicted by EMA criteria or isolated MRI activity in multiple sclerosis. Mult. Scler., 2014, 20(5), 566-576.

[http://dx.doi.org/10.1177/1352458513502399] [PMID: 23999607]

[92] Giovannoni, G.; Soelberg Sorensen, P.; Cook, S. Safety and efficacy of cladribine tablets in patients with relapsing-remitting multiple sclerosis: Results from the randomized extension trial of the CLARITY study. Mult. Scler., 2017, ••1352458517727603 [PMID: 28870107]

[93] Giovannoni, G. Cladribine to Treat Relapsing Forms of Multiple Sclerosis. Neurotherapeutics, 2017, 14(4), 874-887. [http://dx.doi.org/10.1007/s13311-017-0573-4] [PMID: 29168160]

[94] Cook, S.; Vermersch, P.; Comi, G.; Giovannoni, G.; Rammohan K.; Rieckmann, P.; Sørensen, P.S.; Hamlett, A.; Miret, M.; Weiner, J.; Viglietta, V.; Musch, B.; Greenberg, S.J. Safety and tolerability 
of cladribine tablets in multiple sclerosis: the CLARITY (CLAdRIbine Tablets treating multiple sclerosis orallY) study. Mult. Scler., 2011, 17(5), 578-593.

[http://dx.doi.org/10.1177/1352458510391344] [PMID: 21228029]

[95] Soelberg-Sorensen, P.D.F.; Hicking, C.; Giovannoni, G. Absolute lymphocyte count recovery in patients with relapsing-remitting multiple sclerosis (RRMS) treated with cladribine tablets $3.5 \mathrm{mg} / \mathrm{kg}$ in CLARITY and CLARITY Extension (P5.379). Neurology, 2017, 88(16)(Suppl.)

[96] Baker, D.; Herrod, S.S.; Alvarez-Gonzalez, C.; Zalewski, L.; Albor, C.; Schmierer, K. Both cladribine and alemtuzumab may effect MS via B-cell depletion. Neurol. Neuroimmunol. Neuroinflamm., 2017, 4(4)e360

[http://dx.doi.org/10.1212/NXI.0000000000000360] [PMID: 28626781] 